\title{
Per aurem intrat Christus in Mariam. Aproximación iconográfica a la conceptio per aurem en la pintura italiana del Trecento desde fuentes patrísticas y teológicas
}

\author{
José María SALVADOR GONZÁLEZ \\ Universidad Complutense de Madrid \\ jmsalvad@ucm.es
}

\section{RESUMEN}

La tesis mariológica de la conceptio per aurem, según la cual la Virgen María habría concebido a Jesucristo por el oído en el momento de escuchar del ángel el mensaje celestial anunciándole que, sin perder su virginidad, sería madre del Hijo de Dios encarnado, ha merecido hasta ahora muy pocos estudios académicos rigurosamente fundados en fuentes primarias. De hecho, en la literatura especializada son muy escasas las referencias a tal teoría y, cuando algún estudioso la evoca, casi siempre se contenta con aludir a ella, sin aportar pruebas documentales. Sin embargo, tal como lo revelan las nueve pinturas italianas aquí analizadas, esa teoría fue ilustrada mediante sutiles metáforas visuales en muchas obras pictóricas medievales, las cuales se inspiraron en una sólida tradición literaria. Además una pléyade de Padres de la Iglesia y teólogos medievales testimonia, mediante afirmaciones explícitas, que semejante teoría gozó de notable aceptación entre los maestros del pensamiento cristiano. Basándose en numerosos textos patrísticos y teológicos, este artículo intenta dos objetivos esenciales: exponer, ante todo, las distintas formulaciones teóricas propuestas por esos pensadores; y además, tratar de poner en luz los significados dogmáticos que subyacen bajo esa sorprendente tesis.

Palabras clave: Arte medieval, iconografía, mariología, patrística, teología, Anunciación, encarnación de Cristo, pintura italiana del Trecento, conceptio per aurem.

Per aurem intrat Christus in Mariam. Iconographic approach to the conceptio per aurem in Italian Trecento painting from patristic and theological sources

\begin{abstract}
The mariological thesis of the conceptio per aurem, according to which the Virgin Mary would have conceived Jesus Christ through the ear at the instant of hearing the angel's heavenly message announcing her that she would be mother of the Son of God incarnate without losing her virginity, has received so far very few academic studies rigorously grounded in primary sources. In fact the references to this theory in the specialized literature are very scarce and, when a scholar evokes it, he almost always only alludes to it, without providing documentary evidence. However, as the nine Italian paintings discussed here reveal, this theory was illustrated by subtle visual metaphors in many medieval paintings, which were inspired by a strong literary tradition. In addition a pleiad of Church Fathers and medieval theologians
\end{abstract}


testify, by explicit statements, that such a theory enjoyed remarkable acceptance among teachers of Christian thought. Based on many patristic and theological texts, this paper attempts two main purposes: firstly, to expose the various theoretical formulations proposed by these thinkers; then to try to highlight the dogmatic meanings that underlie this astonishing thesis.

Keywords: Medieval Art, Iconography, Mariology, patristics, theology, Annunciation, Incarnation of Christ, Italian Trecento painting, conceptio per aurem.

SUMARIO: 1. Hacia una puesta en perspectiva. 2. La representación de la conceptio per aurem en la pintura italiana del Trecento. 3. La doctrina de la conceptio per aurem en la tradición patrística y teológica. 4. Conclusión 5. Fuentes y bibliografía.

FECHA DE RECEPCIÓN: 21 DE 07 DE 2014

FECHA DE ACEPTACIÓN: 18 DE 09 DE 2014

\section{HACIA UNA PROPUESTA EN PERSPECTIVA}

En el complejo sistema de la mariología ${ }^{1}$ tuvo especial vigencia durante largos siglos de la Antigüedad Tardía y la Edad Media la tesis de la conceptio per aurem. Conforme a tal creencia, la Virgen María habría concebido a Jesucristo por el oído, o, para ser más exacto, tras escuchar y aceptar la propuesta divina -transmitida por el arcángel Gabriel- de convertirse, sin dejar de ser virgen, en madre del Hijo de Dios encarnado ${ }^{2}$.

Ahora bien, pese a su comprobada pervivencia durante más de un milenio -desde, al menos, el siglo IV hasta el XV-, no deja de sorprender la constatación de que esa teoría mariológica haya sido hasta ahora eludida por casi todos los expertos modernos, debido tal vez a cierta incapacidad para documentarla con pruebas fehacientes o quizá por serles del todo desconocida ${ }^{3}$. Sintomático es, en tal sentido, el hecho de que en sus respectivos artículos monográficos de 1924 sobre la Anunciación, insertos en el monumental Dictionnaire d'Archéologie Chrétienne et de Liturgie ${ }^{4}$, sus directores Fernand $\mathrm{Cabrol}^{5}$ y Henri Leclercq ${ }^{6}$ omiten por completo referirse al tema

\footnotetext{
${ }^{1}$ Sobre mariología en general pueden consultarse con provecho varias voces específicas en algunos clásicos diccionarios de doctrina católica, como DTC 1999-1950, 15 vols. dobles (30 tomos); DACL 19241954, 12 vols.; y Enc. Catt. 1948-1954, 12 vols.

${ }^{2}$ Se ha repetido hasta la saciedad el error de que la creencia de esa conceptio per aurem en María lo inició el apócrifo Evangelio Armenio de la Infancia (fechable hacia el siglo VI). Sin embargo, como constataremos en el tercer apartado, ya desde mediados del siglo IV, dos centurias antes de la presunta redacción de dicho apócrifo, algunos Padres de la Iglesia, como San Efrén de Siria y San Zenón de Verona, expresaron de manera explícita la idea de la concepción por el oído en la Anunciación. Son aún más numerosos los autores eclesiásticos que defendieron esa tesis en los siglos V y VI. Por tal motivo, no parece pertinente seguir afirmando que El Evangelio Armenio de la Infancia es la fuente originaria del tema que estudiamos.

${ }^{3}$ Dentro de la abundantísima bibliografía sobre iconografía mariana en general, véanse, a título de ejemplo, los siguientes estudios: Vloberg 1954 (1933); Trens 1947; Verdon 2004; Thérel 1984; Schiller 1980.

${ }^{4}$ DACL 1924-1954, 12 vols.

5 Cabrol 1924, col. 2241-2255.

${ }^{6}$ Leclercq 1924, col. 2255-2267.
} 
que analizamos. Similar omisión se aprecia en el análogo artículo de la Enciclopedia Cattolica del Vaticano?

A decir verdad, son muy exiguos en la literatura especializada ${ }^{8}$ los abordajes rigurosamente documentados a dicha creencia, al extremo de que, cuando algún estudioso la evoca, casi siempre se conforma con mencionarla de paso, sin analizarla en profundidad y, sobre todo, sin aportar evidencias documentales.

Así, por ejemplo, en la temprana fecha de 1914 el psicoanalista galés Ernest Jones es uno de los primeros en abordar el tema ${ }^{9}$, en su artículo «The Madonna's conception through the ear. A contribution to the relation between aesthetics and religion», editado originalmente en la revista alemana Jahrbuch der Psychanalyse, 1914, Band VI, y reimpreso nueve años más tarde como el Capítulo VIII del libro del mismo autor Essays in Applied Psycho-Analysis $(1923)^{10}$. En ese texto el autor, basándose en una abundante serie de referencias comparativas a la antropología y la lingüística, intenta explicar en clave psicoanalítica la -así denominada por él- «leyenda» medieval de la conceptio per aurem. No es nuestro propósito aquí debatir sobre las premisas teórico-metodológicas, las comparaciones interculturales, las proyecciones interpretativas y las conclusiones inferidas por Jones a partir de sus peculiares presupuestos freudianos. Nos interesa, por el contrario, poner en evidencia los graves errores en que incurre al presentar como presuntas fuentes de la creencia en estudio algunas breves y descontextualizadas citas de maestros de la doctrina cristiana.

Así, por ejemplo, Jones atribuye a San Agustín de Hipona la frase «Deus per angelum loquebatur et Virgo per aurem impraegnebatur», que cita como extraída de un supuesto Sermo de Tempore, XXII ${ }^{11}$. Copiada, al parecer, por Jones del ya mencionado artículo escrito un quinquenio antes por Yrjo Hirn ${ }^{12}$ (sin citarlo), esa presunta frase del Hiponense -que, como veremos luego, será repetida sin rigor crítico por numerosos investigadores ${ }^{13}$ - es del todo falsa. De hecho, en ninguna parte del abundantísimo corpus doctrinal de San Agustín -ni en los nueve volúmenes de la Patrología Latina de J-P Migne ${ }^{14}$, ni en los cuarenta y un volúmenes de las Obras Completas de San Agustín, editadas por La Editorial Católica en edición crítica bilin-

\footnotetext{
${ }^{7}$ VV.AA., «Annunciazione», Enc. Catt. 1948, vol. I, col. 1382-210.

${ }^{8}$ Entre algunos acercamientos focalizados a la figura de la Virgen María como modelo del arte y la cultura medieval europea podemos destacar: Iogna-Prat, Palazzo y Russo (eds.) 1996; Norman 1999; Katz, (ed.) 2001 .

9 A nuestro conocimiento, en 1909, cinco años antes del texto de Ernest Jones, Yrjo Hirn se había referido a este tópico mariano en su estudio Hirn 1909 (al que no hemos tenido acceso), del que el propio Jones parece haber tomado algunos datos, como veremos a continuación.

10 Jones 1914 (reimpr. 1923), 261-359.

11 Jones 1914 (reimpr. 1923), 264.

${ }^{12}$ El origen de esa cita atribuida de modo incorrecto a San Agustín parece ser Yrjo Hirn en su mencionado artículo de 1909 (cfr. Steinberg 1987, 27, n. 18).

13 Entre ellos podemos citar, además de Ernest Jones, a Réau 1957, 190; Steinberg 1987, 27, n. 18; McMurray Gibson 1994, 214, n. 25; Baert 2014, en sus correspondientes textos que revisaremos a continuación.

14 Augustinus, Sanctus. PL 32-40.
} 
güe ${ }^{15}$ - hemos encontrado rastro alguno de ese presunto Sermo de Tempore, XXII, ni de esa sugestiva frase atribuida al santo de Hipona. En el Migne, los dos únicos opúsculos de San Agustín que vagamente se parecen al citado por Hirn y Jones son los siguientes: Sermo XXII, De versu 3 Psalmi LXVII ${ }^{16}$, el cual versa sobre la humildad y la vanidad del ser humano, la penitencia y otros temas morales; y Sermo de tempore barbarico (catalogado además entre los sermones de dudosa autoría del santo) ${ }^{17}$, que trata sobre penitencia, paciencia y otros tópicos ascéticos y morales. Ninguno de esos dos Sermones de San Agustín, ni -a nuestro conocimiento- ningún otro texto del Hiponense incluye la citada máxima, razón por la cual esa presunta cita de San Agustín debe considerarse espuria. La duda se extiende hasta el extremo de preguntar si podrá encontrarse en buena hora algún escritor eclesiástico - ¿y quién sería?- que hubiera podido formular tan elusiva frase.

Por otra parte, Ernest Jones se equivoca de plano al citar como de San Agobardo la afirmación «Descendit de coelis missus ab arce patris, introivit per aurem Virginis in regionem nostram indutus stola purpurea et exivit per auream portam lux et Deus universae fabricae mundi ${ }^{18}$, falsa atribución que será luego repetida acríticamente por otros investigadores ${ }^{19}$. Ahora bien, en su Liber de Correctioni Antiphonarii ${ }^{20}$, San Agobardo de Lyon copia esa frase ${ }^{21}$-que es precisamente un versículo de una antífona incluida en un Antifonario litúrgico en uso para entonces- para combatirla de frente y refutarla apodícticamente, por considerarla irracional y herética en varios aspectos, que sustenta con los siguientes argumentos.

Tras acotar de entrada que esa frase antifonaria no precisa quién es el que desciende de los $\operatorname{cielos}^{22}$, San Agobardo añade que esta se equivoca al hablar de «la ciudadela del Padre» (ab arce Patris), pues cómo sería posible que exista en el cielo espiritual un edificio material que hubiese sido hecho por este, $o$, menos aún, que fuese distinto de Dios Padre o que se identificase con Él, y, de ser así, cómo podría ser Dios Padre una ciudadela para sí mismo ${ }^{23}$.

\footnotetext{
15 Obras completas de San Agustín 1977-1995, 41 vols.

16 PL 38, 148-155.

17 PL 40, 699-708.

18 Jones 1914 (reimpr. 1923), 264.

19 Entre otros, Steinberg 1967, y Baert 2014.

${ }^{20}$ Lib. Correct. Antiph., VII-VIII. PL 104, 331-332.

${ }^{21}$ Dicho sea de paso, Jones lee en forma incorrecta dicha frase, pues donde este transcribe inexactamente «et Deus universae fabricae mundi», el texto original de San Agobardo expresa: «et decus universae fabricae mundi» (San Agobardo, Lib. Correct. Antiph., VII-VIII. PL 104, 332). Los énfasis en ambas frases son nuestros. Como se ve, la transcripción de Jones altera sustancialmente el sentido del versículo original de la antífona, pues confundir decus (decoro, ornato, belleza, esplendor, honor) con Deus (Dios) no es precisamente peccata minuta.

22 «Ubi primum, qui descenderit non designat.» (San Agobardo, Lib. Correct. Antiph., VII-VIII. PL 104, $332)$.

23 «Arcem vero Patris quid dixerit, ipse quoque penitus ignoravit. Nunquid est aliquod aedificium coeleste, aut percoeleste, quod factum sit ab eo, aut aliud aliquid quod non est ipsum quod Pater, aut est ipse Pater? Quod si est, quomodo sibi est arx?» (San Agobardo, Lib. Correct. Antiph., VII-VIII. PL 104, 332).
} 
En un nuevo paso de su condena a ese versículo, San Agobardo subraya que, según la doctrina católica, el Verbo de Dios no se introdujo por el oído de la Virgen ( $\mathrm{Nec}$ per aurem Virginis Verbum Dei introisse), pues, siendo incorpóreo y omnipresente, ni accede a ningún lugar concreto ni necesita de ningún revestimiento corpóreo, a no ser que el tal versículo haya querido convencernos de que la Virgen concibió al Hijo de Dios por el sonido de las palabras del ánge ${ }^{24}$.

San Agobardo rechaza también esa última interpretación «débil» del asunto, insistiendo en que la verdad de la doctrina cristiana en este ámbito se condensa en la respuesta del arcángel cuando María le preguntó cómo podría ser madre sin conocer varón: «El Espíritu Santo vendrá sobre ti y el poder del Altísimo te cubrirá con su sombra ${ }^{25}$.» El santo obispo insiste además en la imposibilidad de entender el seno de la Virgen como «nuestra región» o condición (regio nostra), pues ella engendró virginalmente al Hijo de Dios unigénito, mientras nosotros nacemos no virginalmente, sino de una carne corrompida ${ }^{26}$.

Por si fuera poco, San Agobardo considera que la antífona en cuestión incurre en evidentes blasfemias al afirmar que el Hijo de Dios se introdujo por la oreja de la Virgen cubierto con un vestido de púrpura (quod eum stola indutum purpurea aurem dicit Virginis introiisse), o con algún otro indumento regio, o que recibió la naturaleza humana no de la Virgen, sino que la trajo ya hecha del cielo, como si fuese un vestido de púrpura ${ }^{27}$.

Por último, San Agobargo critica la vanidad de la antífona analizada por atreverse a decir que la luz y el Dios de toda la fábrica del mundo salió (nació) por la puerta áurea (Jam vero per auream portam eum exiisse, quanta vanitate proferre aussus est). Concluye el santo subrayando la necesidad de discurrir sobre el nacimiento virginal de Cristo no con palabras vacías, sino desde la fe simple, pues, según la verdad de los Evangelios, Él no es la luz de todos los seres del mundo, sino solo de las creaturas racionales ${ }^{28}$.

\footnotetext{
${ }^{24}$ «Nec per aurem Virginis Verbum Dei introisse, catholicae aures ferunt: quia cum sit incorporeum, et totum ubique praesens, nec localiter accedit, nec aditu corporeo indiget. Nisi forte nobis persuadere voluit angelicorum sono verborum sacram Virginem Dei Filium concepisse.» (San Agobardo, Lib. Correct. Antiph., VII-VIII. PL 104, 332).

25 «Quod quantum a fidei veritate discordet, ex verbis ipsius angeli perspicuum est; qui ipsi Virgini interroganti: Quomodo fiet istud, quia virum non cognosco? Respondit: Spiritus sanctus superveniet in te, et virtus Altissimi obumbrabit tibi.» (San Agobardo, Lib. Correct. Antiph., VII-VIII. PL 104, 332).

${ }^{26}$ «Quomodo autem virginalis uterus regio nostra possit intelligi, cum et virgo illa unici Filii mater sit, et nos omnes non ex virginea sed ex corrupta carne nascamur, prorsus inveniri non potest.» (San Agobardo, Lib. Correct. Antiph., VII-VIII. PL 104, 332).

${ }^{27}$ «Deinde quod eum stola indutum purpurea aurem dicit Virginis introiisse, sive humano more cultu regio indutum, sive humanam formam non ex Virgine suscepisse, sed de coelo Dei Verbum attulisse putaverit, eamque stolam purpuream appellarit, apertissimae blasphemiae est.» (San Agobardo, Lib. Correct. Antiph., VII-VIII. PL 104, 332).

${ }^{28} \ll \mathrm{J}$ am vero per auream portam eum exiisse, quanta vanitate proferre aussus est: cum nativitas Christi ex Virgine non supervacuis verbis adumbrari, sed confessione simplici debeat declarari: qui non, ut ille ait, universae fabricae mundi, sed juxta veritatem evangelicam rationalis tantummodo creaturae lux est.» (San Agobardo, Lib. Correct. Antiph., VII-VIII. PL 104, 332).
} 
Por los argumentos expuestos por el obispo de Lyon, la analizada frase, que Jones da como original de San Agobardo, resulta ser una afirmación por completo ajena a su pensamiento, y, peor aún, que el juzga del todo condenable, por sus múltiples errores y por ser claramente blasfema. Queda patente además que, basándose en lo que él percibe como la ortodoxia cristiana, el prelado lugdunense, lejos de ser un defensor de la tesis de la conceptio per aurem, es un furibundo opositor a ella.

En un nuevo paso de su errática aproximación a las fuentes eclesiásticas, tras citar como de San Efrén de Siria la frase «Per novam Mariae aurem intravit atque infusa est vita» ${ }^{29}$, Ernest Jones añade con pasmosa vaguedad que «similar passages could be quoted from various other Fathers, such as St. Proclus, St. Ruffinus of Aquileia, etc.», sin precisar frases ni textos originales de esos «varios Padres de la Iglesia».

Más sorprendente aún es que Jones atribuya en un par de ocasiones ${ }^{30}$-incluso con una cita textual- a San Zenón de Verona una presunta carta a la emperatriz bizantina Pulcheria, carta sobre la que el psicanalista británico no precisa ningún dato documental ${ }^{31}$. Ahora bien, es este otro craso error en el uso de «fuentes» patrísticas por parte de Jones, tal como lo corroboran estas dos evidencias. Ante todo, entre los escritos de San Zenón, reunidos por J-P. Migne en el Tomo 11 de su Patrología Latina, no aparece ninguna Epístola ad Pulcheriam Augustam, y esto por razones obvias, como veremos a continuación. En segundo lugar, en efecto, mal podría San Zenón (300-† ca. 372), quien fue obispo de Verona entre 362 y 372, haber escrito una carta a la emperatriz Pulcheria (398/99-453), la cual reinó en Bizancio primero como Augusta entre 414 y 450, y luego como emperatriz entre 450 y 453: queda así en evidencia que el prelado veronés - muerto casi tres décadas antes del nacimiento de Pulcheria, y más de cuarenta años antes de que esta fuese designada Augusta - no pudo en ningún momento ser autor de esa supuesta Epistola ad Pulcheriam Augustam. Por el contrario, el papa San León I el Magno (ca. 390-461), además de haber vivido casi al mismo tiempo que Pulcheria -con sus respectivas fechas de nacimiento y muerte bastante cercanas-, escribió numerosas cartas a esta emperatriz bizantina, publicadas con el genérico nombre «Epistola ad Pulcheriam Augustam» (con su correlativa numeración arábiga, para distinguirlas) en la monumental colección Documenta Catholica Omnia ${ }^{32}$. Por tal motivo, lo más probable es que esa presunta cita, que Jones da erróneamente como de San Zenón de Verona, pueda ser atribuida provisionalmente -a falta de comprobación documental- al papa San León Magno. A decir verdad, el hecho de que Jones confunda al relativamente discreto obispo de Verona, San Zenón (del siglo IV) con el presti-

\footnotetext{
${ }^{29}$ Jones lo cita con la siguiente entrada: «St. Ephrem: De Divers Serm. I, Opp Syr, Vol. III, p. 607». Aunque, como veremos en el tercer apartado, presentamos varios pasajes de San Efrén el Sirio en relación al tema de la conceptio per aurem, no hemos podido certificar la exactitud de la cita aportada por Jones, por no haber tenido acceso al libro en traducción latina citado por él.

30 Jones 1914, 289, n. 1, y 324, n. 3.

31 Así lo cita Jones: «St. Zeno, Epist. Ad Pulcheriam Augustam» (sin precisar numeración de la epistola, ni, menos aún, la fuente patrística en que estaría editada dicha epístola.

32 Docum. Cath. Omnia. Magisterium Paparum. Leo I, Magnus, Sanctus.
} 
giosísimo e influyente papa San León Magno (del siglo V) no es tampoco ninguna menudencia excusable.

A la postre, teniendo en cuenta la ineludible necesidad de las fuentes patrísticas y teológicas para fundamentar doctrinalmente la iconografía cristiana, los graves errores cometidos por Ernest Jones al usar algunos textos de autores eclesiásticos, mediante los que pretende explicar la creencia de la conceptio per aurem en la Anunciación, desacreditan de manera significativa el valor epistemológico de su muy celebrado artículo, cualquiera que pueda ser su eventual pertinencia en otros campos, como el psiconálisis, la antropología o la lingüística.

Cuarenta y un años más tarde (1955), Gary A. Anderson, en su libro sobre Adán y Eva en el imaginario judío y cristiano ${ }^{33}$, solo menciona de pasada el tema de la concepción por el oído, al resumir brevemente la conocida antítesis que los teólogos medievales establecieron entre los comportamientos de Eva y María con su sentido del oído 34 : la primera, cuando en desobediencia a Dios escuchó a la serpierte-demonio, produciendo así el pecado y la muerte; la segunda, cuando, al recibir con obediente disponiblidad la palabra divina transmitida por el ángel Gabriel, concibió al Salvador Hijo de Dios ${ }^{35}$.

Un bienio después (1957), Louis Réau, en el capítulo dedicado en su prestigiosa obra a la Anunciación ${ }^{36}$, afirma que respecto a la concepción de Cristo los escritores eclesiásticos medievales se dividían en dos escuelas: algunos defendían que este entró en el seno de María a través de su oído (conceptio per aurem), mientras la mayoría de ellos planteaba que la Virgen concibió a Jesús por la vía normal (conceptio per uterum $)^{37}$. Al margen de tan explícito enunciado, el autor no menciona ni un solo texto patrístico o teológico que proponga y defienda esa preñez por el oído. Réau establece un estrecho vínculo - casi una identidad- entre la idea de la conceptio per aurem y la representación plástica de Cristo como un minúsculo niño (feto) en el vientre de María o proyectado hacia su oído, representaciones ambas que de manera bastante excepcional se observa en algunas Anunciaciones pictóricas medievales eu-

\footnotetext{
33 Anderson 1955.

${ }^{34}$ Uno de los primeros pensadores cristianos en formular esa antítesis Eva/María en lo referente a comportamiento de sus respectivas orejas es San Justino a mediados del siglo II.

${ }^{35}$ Así lo expresa Anderson: «In fact, few Christian sources repeated the lewdest form or this tradition [la judía], that Eve actually had sexual relations with serpent. Christian writers preferred to speak of Eve's conception of death (not Cain) through her obedience to the snake's word, or verbal suggestion. Through her ear, the organ of hearing, Eve conceived desease, decay, and death. Mary, on the other hand, knew an obedience of a different order. Her receptive ear to the word of the angel Gabriel resulted in the conception of the Son of God. This tradition of "conceiving through (obedient) hearing," conceptio per aurem, tranformed the point of emphasis from carnal knowledge to an act of reasoned understanding and willed obedience.» (Anderson 1955, 92).

36 Réau 1957, 190s.

37 «Par quelle voie s'était opérée l'Incarnation? Les théologiens se partageaient sur ce point en deux Écoles. Les uns soutenaient que le Christ, qui est le Logos, le Verbe, était entré par l'oreille de la Vierge en même temps que le message de l'ange annonciateur: Virgo per aurem impregnatur (sic). C'est le thème de la Conceptio per aurem. (...) Mais la plupart croyaient que la conception s'était faite plus normalement para le canal utérin (Conceptio per uterum).» (Réau 1957, 190). Parece claro que esa frase latina, transcrita incorrectamente y sin citar la fuente, la ha tomado Réau (sin citarlo tampoco) de Yrjo Hirn o, con mayor probabilidad, de Ernest Jones, según lo que explicamos en párrafos precedentes.
} 
ropeas. A juicio de este iconógrafo francés, semejante representación de Cristo/niño, que él considera de origen bizantino, se propagó por Europa a partir del siglo XIV ${ }^{38}$, antes de ser - tras las protestas de algunos ilustres teólogos- prohibida por el Concilio de Trento a mediados del siglo XVI ${ }^{39}$.

Con análoga postura, casi una década más tarde (1966), Gertrud Schiller, en su rigurosa obra sobre la iconografía cristiana ${ }^{40}$, estudia con amplitud el tema de la Anunciación $^{41}$. Al discurrir allí sobre los posibles motivos por los que, en las imágenes de este episodio mariano, se generaliza desde el siglo XI la presencia de la paloma del Espíritu Santo, la autora sugiere la tesis de la concepción por el oído. Lo extraño del caso, sin embargo, es que Schiller mencione este asunto con la escueta frase «There was considerable insistence also upon conceptio per aurem (conception through the ear) ${ }^{42}$, sin mencionar siquiera un solo nombre de Padre de la Iglesia o teólogo que la defienda.

Cuatro años después (1970) W. Kindler publica el breve artículo «Representation of the 'conceptio per aurem' in the Christian culture area of the middle ages». ${ }^{43}$ Pese a no haber podido consultarlo, este escrito luce desde afuera -y suponemos no desacertada nuestra intuición- de escaso interés para el tema que estudiamos desde nuestro enfoque epistemológico: así lo permite suponer no solo su breve extensión (apenas seis páginas), sino además su presunto enfoque meramente fisiológico, dado que el artículo se publicó en una revista de otorrinolaringología.

Algo más de tres lustros después (1987) Leo Steinberg publicó el artículo «'How shall this be?' Reflections on Filippo Lippi's “Annunciation” in London, Part I», ${ }^{44}$ en el que busca interpretar en forma personal ese cuadro del pintor italiano, explicando el embarazo de María no según la idea de la conceptio per aurem, sino, al contrario, como resultado de la mirada de Dios (el Espíritu Santo), siguiendo análogamente la teoría vigente en el siglo XV sobre el proceso de la visión. Nuestro interés aquí no es discutir esa interpretación -por sugerente que sea-, sino poner de relieve las debilidades de este historiador al presentar ciertas citas de autores eclesiásticos como bases doctrinales de la tesis de la concepción por el oído.

38 «Ce thème est sans doute d'origine byzantine: car on voit dans les icônes russes de l'Annonciation l'Enfant Jésus déjà dans le sein de la Vierge (...). Il apparaît en Italie au début du XIV siècle, plus tardivement en France, en Flandre et en Allemagne.» (Réau 1957, 190s).

39 «Dans le XV siècle des protestations se font déjà entendre contre ce sujet choquant. Il ne s'agit pas, il est vrai, de défendre le bon goût outragé ou la simple décence, mais l'orthodoxie en péril. L'archevêque de Florence, Saint Antonin, blâme les peintres qui représentent l'Enfant Jésus projeté tout formé dans le sein de la Vierge comme si son corps ne s'était pas nourri de la substance maternelle. Le Concile de Trente s'associe à cette condamnation et le fameux théologien Molanus de Louvain se fait son interprète en proscrivant du répertoire de l'art catholique les Annonciations où l'on voit «corpusculum quoddam humanum descendens inter radios ad uterum Beatissimae Virginis», comme si, ajoute-t-il, le sein de la Vierge n'avait été qu'un simple tuyau ou chalumeau (fistula) par où serait entré et sorti le corps du Christ formé dans le ciel.» (Réau 1957, 191).

40 Schiller 1971 (1966).

41 Schiller 1971 (1966), 33-55.

42 Schiller 1971 (1966), 43.

43 Kindler 1970, 696-702.

44 Steinberg 1987, 25-44. 
Y es que, en lugar de consultar por sí mismo las fuentes primarias, Steinberg se contenta con copiar citas cristianas de otros autores (a menudo, sin precisar las respectivas fuentes teológicas), reiterando a veces las inexactitudes y errores en que algunos de ellos incurren, tal como ya reseñamos en párrafos precedentes. Por mencionar algunos casos, Steinberg reincide en los ya criticados desatinos de Yrjo Hirn y Ernest Jones (la espuria frase «Virgo per aurem impraegnebatur», dada como de San Agustín), ${ }^{45}$ y del mismo Jones (la falsa cita de San Agobardo). ${ }^{46}$ Por lo demás, Steinberg se obstina en presentar en forma indirecta las citas de las fuentes eclesiásticas, transcribiéndolas de otros historiadores contemporáneos, como se ve en los siguientes datos: de Hirn copia sendas frases de San Gaudencio y San Bernardo $;{ }^{47}$ de Ernest Jones reproduce citas de San Zenón y San Efrén; ${ }^{48}$ de Thomas Livius trasiega enunciados de San Ambrosio, San Eleuterio, Esiquio, San Fulgencio y San Zenón; ${ }^{49}$ de Samuel J. Eales retoma una sentencia de Santo Tomás de Aquino, ${ }^{50}$ y de Hans von Campenhausen se apropia de un dicho de San Ireneo de Lyon. ${ }^{51}$ En tal sentido, cuando se pretende certificar con rigor epistemológico alguna hipótesis, luce innecesario llamar la atención sobre el enorme riesgo y el escaso valor académico que supone suplantar, como lo hace Steinberg, la consulta directa de las fuentes primarias (si están disponibles) con el cómodo uso indirecto de bibliografía secundaria.

En 1991 la coptologista polaca Katarzyna Urbaniak-Walczak ${ }^{52}$ defendió en la Universidad de Münster (Westfalen) la tesis doctoral Die «conceptio per aurem»: Untersuchungen zum Marienbild in Ägypten unter besonderer Berücksichtigung der Malereien in El-Bagawat. ${ }^{53}$ Por no estar incluido en los fondos bibliográficos de ninguna biblioteca pública en España, no hemos podido consultar este libro, que sin duda habría enriquecido en medida considerable nuestro planteamiento. Así nos lo permiten conjeturar tanto su directo y específico abordaje del tema bajo escrutinio -al estudiar la imagen de María en el arte copto, pone especial énfasis en la concepción por el oído, a juzgar por su título-, como su vasta extensión y su indudable profundidad y rigor académicos (al tratarse de una tesis doctoral en Alemania).

Un trienio más tarde (1994) Gail McMurray Gibson, en su libro The Theater of Devotion: East Anglian Drama and Society in the Late Middle Ages,${ }^{54}$ se conforma con una simple mención a la conceptio per aurem en la nota 25 de su página 214, repitiendo de paso el ya mentado error de atribuir a San Agustín (sin citar ninguna

45 Steinberg 1987, 27, n. 18.

${ }^{46}$ Steinberg 1987, 27, n. 19.

${ }^{47}$ Steinberg 1987, 27, n. 19, y 29, n. 24, respectivamente.

${ }^{48}$ Steinberg 1987,27, n. 17.

49 Steinberg 1987,25 , n. $1 ; 27$, n. $18 ; 28$, n. $22 ; 35$, n. 34, y 35, n. 35 , respectivamente.

${ }^{50}$ Steinberg 1987, 25, n. 2.

${ }^{51}$ Steinberg 1987, 27, n. 13.

52 Prematuramente fallecida en 2003 a los 47 años, Katarzyna Urbaniak-Walczak era Conservadora de Arte Copto en el Museo Nacional de Varsovia.

${ }_{53}$ Urbaniak-Walczak 1991.

${ }^{54}$ McMurray Gibson 1994, 252 p. 
fuente) el dicho «et virgo per aurem impregnebatur (sic)», ${ }^{55}$ establecido, como vimos, por Yrjo Hirn (1909) y repetido luego por Ernest Jones (1914).

Una similar ligera alusión al tema bajo análisis realiza dos años después (1996) Julio I. González Montañés, en su artículo «Parvulus Puer in Annuntiatione Virginis. Un estudio sobre la iconografía de la Encarnación». ${ }^{56}$ En la nota 8 de la página 13 de su texto, dicho autor retoma los conocidos tópicos sobre el supuesto origen de esa tesis mariana en el Evangelio Armenio de la Infancia, las contrapuestas opiniones de los teólogos medievales defensores de dos alternativas doctrinales (la conceptio per aurem frente a la conceptio per uterum), y el paralelismo entre nuestro tema y la antítesis Eva/María, establecida por algunos escritores sacros. ${ }^{57}$

De 2003 data la publicación del trabajo de Nicholas Constas, Proclus of Constantinopole and the Cult of the Virgin in Late Antiquity: homilies 1-5, texts and translations. ${ }^{58}$ Aunque restringido esencialmente a la doctrina de San Proclo, ${ }^{59}$ este amplio libro, del que solo hemos podido leer algunas páginas disponibles en internet, parece resultar -sobre todo su Capítulo 5: «'The ear of the virginal body': The poetics of sound in the school of Proclus» (p. 273-314)- indispensable a la hora de estudiar en forma exhaustiva la teoría cristiana de la conceptio per aurem en la Anunciación. La lectura de este libro se nos presenta, a no dudarlo, como obligada tarea para un próximo futuro.

55 «The actual phrase that the most revered of early Christian exegetes, Augustine, had used to describe the mysterious procreative faith that 'cometh from hearing' (cf. Romans $10: 17$ ) was 'et virgo per aurem impregnabatur' ('the Virgin through the ear was impregnated'). Augustine's metaphor had by the ninth century come to be invoked as a physical description of the Conception mystery. Christ the Word (cf. John 1:1) had been miraculously conceived through the most appropriate orifice -the ear; by the late Middle Ages the doctrine of the conceptio per aurem (conception through the ear) was ubiquitous in Marian hymns and devotional poems.» (McMurray Gibson 1994, 214, n. 25).

${ }^{56}$ González Montañés 1996, 11-45.

${ }^{57}$ Así lo expresa González Montañés: «En ocasiones [la paloma del Espíritu Santo] aparece situada sobre la cabeza de la Virgen, haciendo visibles las palabras del Evangelio «El Espíritu Santo vendrá sobre ti, y la virtud del Altísimo te cubrirá con su sombra» (Lc. I, 35), aunque es más frecuente representarla descendiendo hacia la oreja de María en referencia a la doctrina de la conceptio per aurem planteada en los apócrifos (Evangelio armenio de la infancia, V, 9) y adoptada por buena parte de la tradición patrística desde el siglo IV. El Verbo habría penetrado en María a través de la oreja, al mismo tiempo que el mensaje del ángel. Esta doctrina, aunque minoritaria frente a los defensores de la conceptio per uterum, mantuvo su vigencia a lo largo de los siglos interpretada en un sentido no estrictamente material; en virtud de la fe (conceptio per fidem), la concepción tuvo lugar en el intelecto de María antes de tener físicamente a Jesús en su seno («aquel que é contigo na mente, seja contigo no ventre» dice la versión portuguesa de la Vita Christi de Ludolfo de Sajonia, cap. V, n 166 ). Tal concepción «por la oreja» se vería ademas apoyada por la existencia de un antetipo en las palabras del Salmo 45, 11: «Oye, hija, y mira; inclina tu oído:/ olvida tu pueblo y la casa de tu padre», además de aparecer prefigurada por antítesis en el episodio de Eva y la Serpiente. Del mismo modo que el demonio, a través de la persuasión, hablando a la oreja de Eva, introdujo el pecado en el mundo, también a través de la oreja entró Jesús en María, la nueva Eva que borra el pecado de su antecesora (...). Son numerosos los textos en los que se hace referencia a la conceptio per aurem pero quizá los más conocidos sean los versos atribuidos a Santo Tomas Becket:

Gaude, Virgo, mater Christi

Quae per aurem concepisti!' (González Montañés 1996, 13, n. 8).

${ }^{58}$ Constas 2003

${ }^{59}$ Véase infra, en nuestro apartado 3, los análisis de las cuatro citas de San Proclo que hemos encontrado en nuestra investigación previa. 
En fecha reciente (2014) Barbara Baert ha abordado nuestro tema en un interesante artículo, en el que propone una nueva lectura de la Anunciación a partir de los sentidos $^{60}$, fundándose para ello en la estrecha relación semántica entre viento/hálito y espíritu/vida. ${ }^{61}$ Pese a lo sugestivo de su enfoque, la autora, al haber asumido del citado artículo de Leo Steinberg las supuestas citas de San Agustín y Agobardo, así como de San Efrén de Siria, ${ }^{62}$ recae en los mismos deslices ya señalados en aquel historiador.

Por último, hace apenas unos meses (fines de 2014), Jacques Poucet, catedrático emérito de la Université Catholique de Louvain, publicaba electrónicamente en una revista digital de su universidad el amplio estudio L'Évangile selon Jean d'Outremeuse (XIVe s.) Autour de la Naissance du Christ (Myreur, I, $p$. 307-347 passim). Commentaire, ${ }^{63}$ en el que aborda nuestro tema en el Capítulo III. «L'Annonciation et la Virginité de Marie», y en especial en su apartado 9. «La "conception par l'oreille" $(\S 8) »($ p. 6-11). Tras relacionar esta creencia cristiana con otras leyendas provenientes de religiones y culturas orientales y occidentales, el autor se limita a presentar aquí - tomándolas de un artículo de François Remigereau ${ }^{64}$ - algunas citas de San Proclo de Constantinopla, San Juan Damasceno, San Efrén el Sirio, Enodio, San Venancio de Poitiers y San Buenaventura.

A la postre, los párrafos precedentes constituyen, en el estado actual de nuestras investigaciones, la magra cosecha de referencias documentales que, sobre la teoría de la conceptio per aurem, pudimos recoger entre los expertos en cultura visual del cristianismo, tanto en su corpus doctrinal como en su iconografia. ${ }^{65}$ Pese a ello, contrastando con tan inexplicables silencios, lagunas y omisiones por parte de los especialistas, intentaremos confirmar en los dos subsiguientes apartados de este artículo la manifiesta pervivencia de esa idea mariológica durante la Edad Media en las imágenes artísticas y, de modo especial, en los textos doctrinales. En el apartado 2 , el análisis de nueve pinturas italianas del Trecento ${ }^{66}$ nos permitirá vislumbrar en

\footnotetext{
60 Baert 2014
}

61 «St. Zeno of Verona (300-371) asserted that Mary's uterus swelled, but from words rather than semen. The invisibility and immateriality of the breath and of speech forms the etymological core of various words that subsequently came to express notions such as spirit, idea, mind. This association is apparent in Greek psyche, Hebrew nephesh, German Geist and English ghost, all of which originally meant 'breath'. This explains the richness of the notion of pneuma, which means wind, breath as well as spirit. In sum, from the roaring wind to the impregnating breath, the foundation is laid for an entity, the Holy Ghost, who has the power to enter the human body.» (Baert 2014, 60).

62 Baert 2014, 66, n. 2.

63 Poucet 2014, s.p.

${ }^{64}$ Remigereau 1947, 115-176.

65 Para un abordaje de la iconografía cristiana en general, véanse sobre todo: Mâle 1898 (reimpr. 1968); Bréhier 1918; Toscano 1960; Mâle (1924) 19667; Mâle 1988; Réau 1957; Schiller 1968-1970; Grabar 1979.

${ }^{66}$ Entre los incontables estudios relativos al arte del Trecento italiano, véanse, entre otros: Offner 1927 (reimpr. 1972); Antal s.a. (1948); Weigelt 1974; Meiss 1965; Oertel 1966; Fremantle 1975; Cole 1976; Smart 1978; Borsook 1980; Cole 1980; Garrison 1984; Hills 1987; Maginnis 1997; Pierini 2001; Limentani y Pietrogiovanna 2001; Maginnis 2001; Schmidt (ed) 2002; Poeschke 2003. 
parte la incidencia de esa fórmula doctrinal sobre el arte europeo. ${ }^{67}$ Por último, en el tercer apartado expondremos numerosos textos patrísticos y teológicos ${ }^{68}$-fuente de inspiración para aquellas imágenes artísticas-, con el propósito de elucidar los significados dogmáticos subyacentes bajo esa singular teoría.

\section{LA REPRESENTACIÓN DE LA CONCEPTIO PER AUREM EN LA PINTURA ITALIANA DEL TRECENTO}

La decisión de elegir la pintura trecentista italiana como núcleo paradigmático para mostrar la inspiradora influencia que la tesis mariológica en estudio ejerció sobre el arte medieval europeo obedece, en esencia, al hecho de que la Italia del siglo XIV es la que mejor representa la extraordinaria pujanza de las ideas teológicas y las imágenes relativas a la conceptio per aurem en la Anunciación: pujanza de ideas, debido a la significativa influencia que la Iglesia - no solo el Papado y el clero secular, sino, en especial, las órdenes religiosas- mantenía sobre la sociedad italiana de entonces; pujanza de imágenes, pues en el arte italiano del Trecento -líder en Europa, y favorecido con una nutrida pléyade de influyentes artistas- se consolida ampliamente la iconografía de la concepción por el oído, que luego alcanzará cotas de superlativa calidad durante el subsiguiente Quattrocento. De hecho, las nueve obras pictóricas trecentistas que analizamos aquí testimonian en forma ejemplar-cada una a su modo y medida-, mediante una variada panoplia de sutiles analogías visuales, la iconografía mariana bajo escrutinio.

Casi finalizando el siglo XIII Jacopo Torriti concluía el monumental ciclo musivo en el ábside de la Basílica de Santa Maria Maggiore en Roma, cuyo programa iconográfico incluye también La Anunciación, 1296 (Fig. 1) ${ }^{69}$. En este mosaico de Torriti el ángel, de amplias alas coloridas, bendice a María, quien, erguida ante un trono inserto en una estructura arquitectónica -cuyos elementos constructivos (ábside, bóveda, decoración cosmatesca) semejan la forma de un templo-, escucha con timidez el mensaje celestial que le promete la maternidad divina sin perder su virginidad. Desde lo alto de la escena Dios Padre, en forma de busto aureolado por un semicircular nimbo azulenco, observa complacido a la Virgen, mientras el Espíritu Santo, representado en forma de diminuta paloma, vuela en la estela del rayo irradiado por el Altísimo

\footnotetext{
${ }^{67}$ Podríamos, sin duda, extender el análisis iconográfico a otras Anunciaciones pictóricas flamencas, españolas, alemanas o de otros países europeos, las cuales ilustran también la idea de la conceptio per aurem. Sin embargo, por «economía» metodológica, restringimos nuestra atención al relativamente homogéneo ámbito de la pintura italiana del Trecento -claramente tipificado como cultura general por específicas circunstancias doctrinales y artísticas-, seleccionando en él las nueve obras pictóricas que mejor nos permiten demostrar el directo y esencial reflejo de esa peculiar hipótesis mariológica en el arte bajomedieval italiano.

${ }^{68}$ Para el estudio de las fuentes patrísticas y teológicas de la mariología resulta de gran importancia la amplia colección de textos compilados en griego y latín por Álvarez Campos 1970-1981, 7 vols. Interesante es también el más restringido estudio de Aldama 1970, 380 p.

69 Jacopo Torriti, La Anunciación, 1296, mosaico. Ábside de la Basílica de Santa Maria Maggiore, Roma.
} 


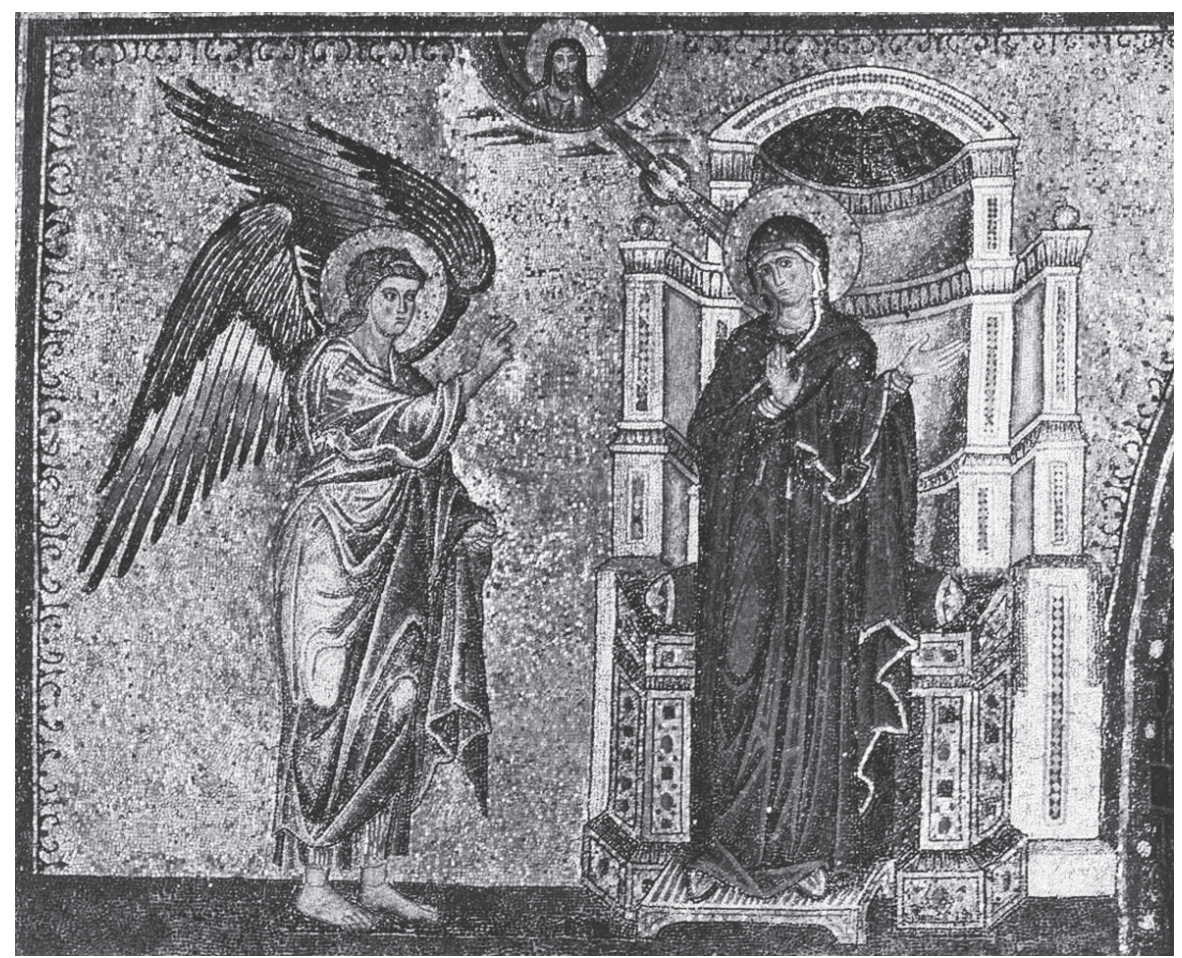

Fig. 1. Jacopo Torriti, La Anunciación, c. 1296. Basílica de Santa Maria Maggiore, Roma. Imagen tomada de Web Gallery of Art. Consultado el 30 de marzo de 2014. URL: w.wga.hu/ support/viewer/z.html

hacia el oído derecho de María para fecundarla. El nudo narrativo-eidético entretejido por las figuras y la escenografía de este mosaico se halla imbuido de profundos significados teológicos. De hecho, la semejanza del trono adoselado a un edificio eclesial podría quizá significar dos metáforas doctrinales, en estrecha relación: ante todo, como metáfora de que el Salvador, ya engendrado desde ese mismo instante en el vientre de María, nacerá para construir el Templo de la Nueva Alianza (la Iglesia cristiana); y además como metáfora de la propia Virgen, identificada alegóricamente con la Iglesia como institución y como asamblea de creyentes cristianos, conforme a la coincidente exégesis de muchos pensadores medievales.

Duccio de Buoninsegna, ${ }^{70}$ en su Anunciación, 1308-1311, de la National Gallery de Londres (Fig. 2) ${ }^{71}$, adopta -inspirándose en tradicionales modelos bizantinos- una estructura compositiva bastante sencilla. Portando en su mano izquierda un largo bá-

\footnotetext{
70 Sobre la obra de Duccio, véanse, por ejemplo, Carli 1961; Stubblebine ca. 1979; Castelnuovo 1985; Carli 1999.

71 Duccio de Buoninsegna, La Anunciación, 1308-1311, temple y oro sobre madera, 43 x 44 cm, originalmente panel de la predela frontal de La Maestà en la catedral de Siena, hoy en la National Gallery de Londres.
} 


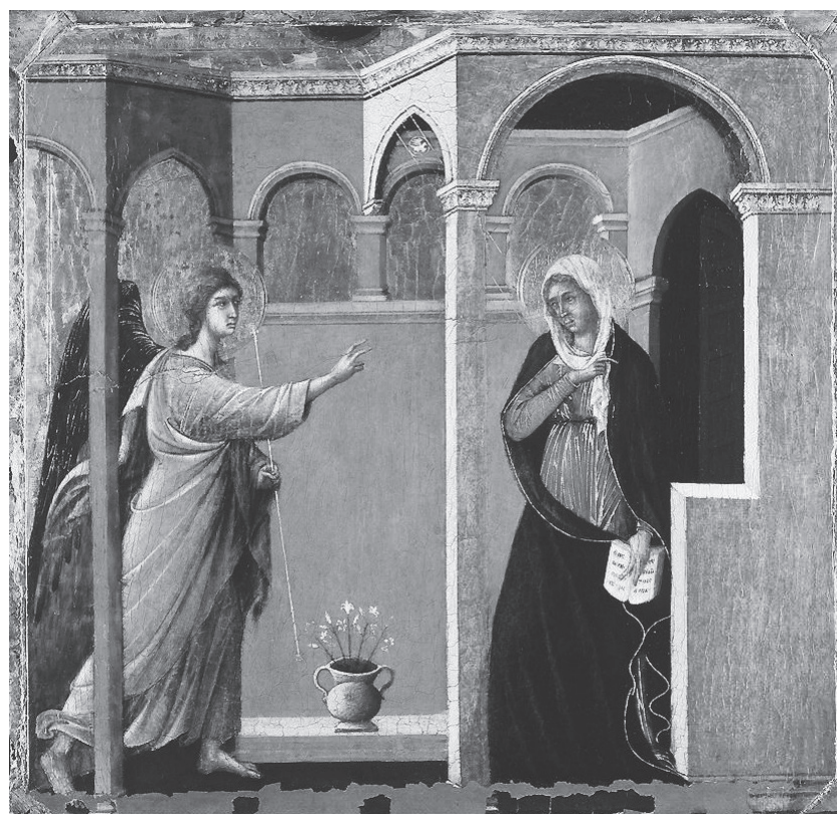

Fig. 2. Duccio, La Anunciación, 1308-1311, antiguo panel de La Maestá. National Gallery, Londres. Imagen tomada de Web Gallery of Art. Consultado el 30 de marzo de 2014. URL: w.wga.hu/support/viewer/z.html

culo, Gabriel franquea a grandes pasos la puerta del aposento de la Virgen, bendiciéndola, mientras esta, sorprendida en pose erguida, expresa su púdico temor, inclinando la cabeza, echando el cuerpo hacia atrás y cubriéndose el torso con el brazo derecho. Sugerido apenas mediante el pequeño arco de círculo azulenco en la cima del cuadro, el Todopoderoso emite el rayo fecundante -vehiculador del Paráclito como ave diminuta- hacia la oreja derecha de María, en clara referencia a su impoluta concepción por el oído. Ese limpio engendramiento del Hijo de Dios encarnado viene también figurado por los lirios que brotan del jarrón, los cuales vinculan visual y conceptualmente a ambos interlocutores.

Simone Martini, en su Anunciación entre los santos Ansano y Margarita, 1333 (Fig. 3), en la Galleria degli Uffizi de Florencia ${ }^{72}$, retoma el tradicional modo gótico de narrar la escena sobre un abstracto fondo de oro, omitiendo toda escenografía, salvo el trono y el florero. Proyectándose sobre ese indefinido trasfondo, el ángel, con su cabeza ceñida con una corona de olivo, se hinca de rodillas ante la entronizada Virgen, ofreciéndole con su mano izquierda un ramo de olivo en signo de paz, mientras le

\footnotetext{
${ }^{72}$ Simone Martini (con la colaboración de Lippo Memmi), La Anunciación entre los santos Ansano y Margarita, 1333, temple y oro sobre madera, 184 x $210 \mathrm{~cm}$. Retablo proveniente de la capilla de Sant'Ansano en la catedral de Siena, Galleria degli Uffizi, Florencia. Las figuras de los dos santos, en los paneles laterales del retablo, se atribuyen a Lippo Memmi.
} 




Fig. 3. Simone Martini, La Anunciación entre los santos Ansano y Margarita, 1333. Galleria degli Uffizi, Florencia. Imagen tomada de Wikimedia Commons. Consultado el 30 de marzo de 2014. URL: http://commons.wikimedia.org/wiki/File:Simone_Martini_truecolor.jpg

señala hacia arriba con su mano derecha para indicarle quién le envía como mensajero ante ella. Por lo demás, Simone Martini introduce aquí una nueva y original forma metafórica de visibilizar la conceptio per aurem. En efecto, aun eliminando el típico aliento/rayo fecundador emitido por el Omnipotente -Dios aparece en este cuadro representado solo por la paloma del Espíritu Santo, en una roja mandorla de querubines-, el artista patentiza esa concepción por el oído mediante la dorada inscripción epigráfica AVE GRATIA PLENA DOMINUS TECUM: saliendo de la boca del ángel, dicha inscripción llega hasta la oreja derecha de María, quien se retrae con modesta turbación sobre su trono, mientras sujeta entreabierto el libro de profecías/oraciones.

Bernardo Daddi (ca. 1280-1348), en su Anunciación, ca. 1335, del Musée du Louvre (Fig. 4) ${ }^{73}$, plasma al arcángel Gabriel -acompañado excepcionalmente por

\footnotetext{
${ }^{73}$ Bernardo Daddi, La Anunciación, c. 1335, temple y oro sobre madera, 43 x $70 \mathrm{~cm}$. Musée du Louvre, París.
} 


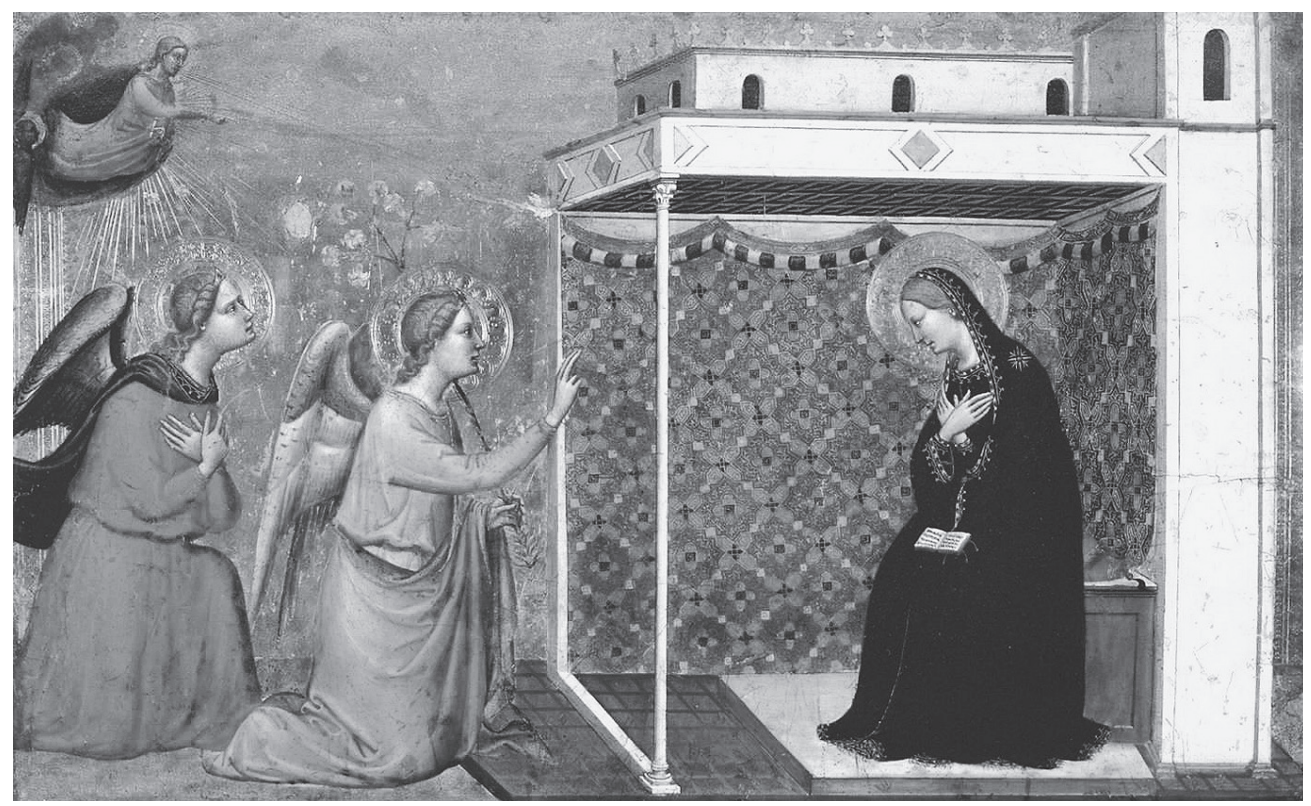

Fig. 4. Bernardo Daddi, La Anunciación, c. 1335. Musée du Louvre, Paris. Imagen tomada de Wikimedia Commons. Consultado el 30 de marzo de 2014. URL: http://commons. wikimedia.org/wiki/File:Bernardo_Daddi_-_Mariae_Verk\%C3\%BCndigung_-_1335_. jpg? uselang=it

otro ángel- portando un ramo de lirios en su mano izquierda, al tiempo que señala con gesto de bendición a María para indicarle su inigualable privilegio de ser «bendita entre todas las mujeres», al haber sido elegida como la Madre del Hijo de Dios hecho carne. Cabizbaja y con las manos cruzadas sobre el pecho, la Virgen recibe el mensaje angélico con humildad y recato. Desde el ángulo superior izquierdo, Dios Padre, orlado de esplendor, señala con su índice a la Madonna, mientras envía hacia su oreja derecha - para fertilizarla mediante la palabra de su mensaje- el divino rayo con la paloma del Paráclito, dador de vida.

Ambrogio Lorenzetti, en La Anunciación, 1344, tabla originalmente ubicada en la Sala del Consistorio del Palazzo Pubblico de Siena ${ }^{74}$, y hoy en la Pinacoteca Nazionale de la misma ciudad (Fig. 5) ${ }^{75}$, ofrece un planteo bastante original respecto a las convenciones sobre este asunto mariano, por haber organizado aquí un diálogo a tres bandas. De hecho, mientras el inicial saludo congratulatorio del ángel, $A V E$ MARIA, GRATIA PLENA, DOMINUS TE[CUM], aparece inscrito en letras doradas

\footnotetext{
74 Dato tomado de Wikipedia. http://it.wikipedia.org/wiki/Annunciazione_(Ambrogio_Lorenzetti) [Acceso: 16/03/2014].

75 Ambrogio Lorenzetti, La Anunciación, 1344, temple y oro sobre madera, 127 x $120 \mathrm{~cm}$. Tabla procedente de la Sala del Consistorio del Palazzo Pubblico de Siena. Pinacoteca Nazionale, Siena.
} 


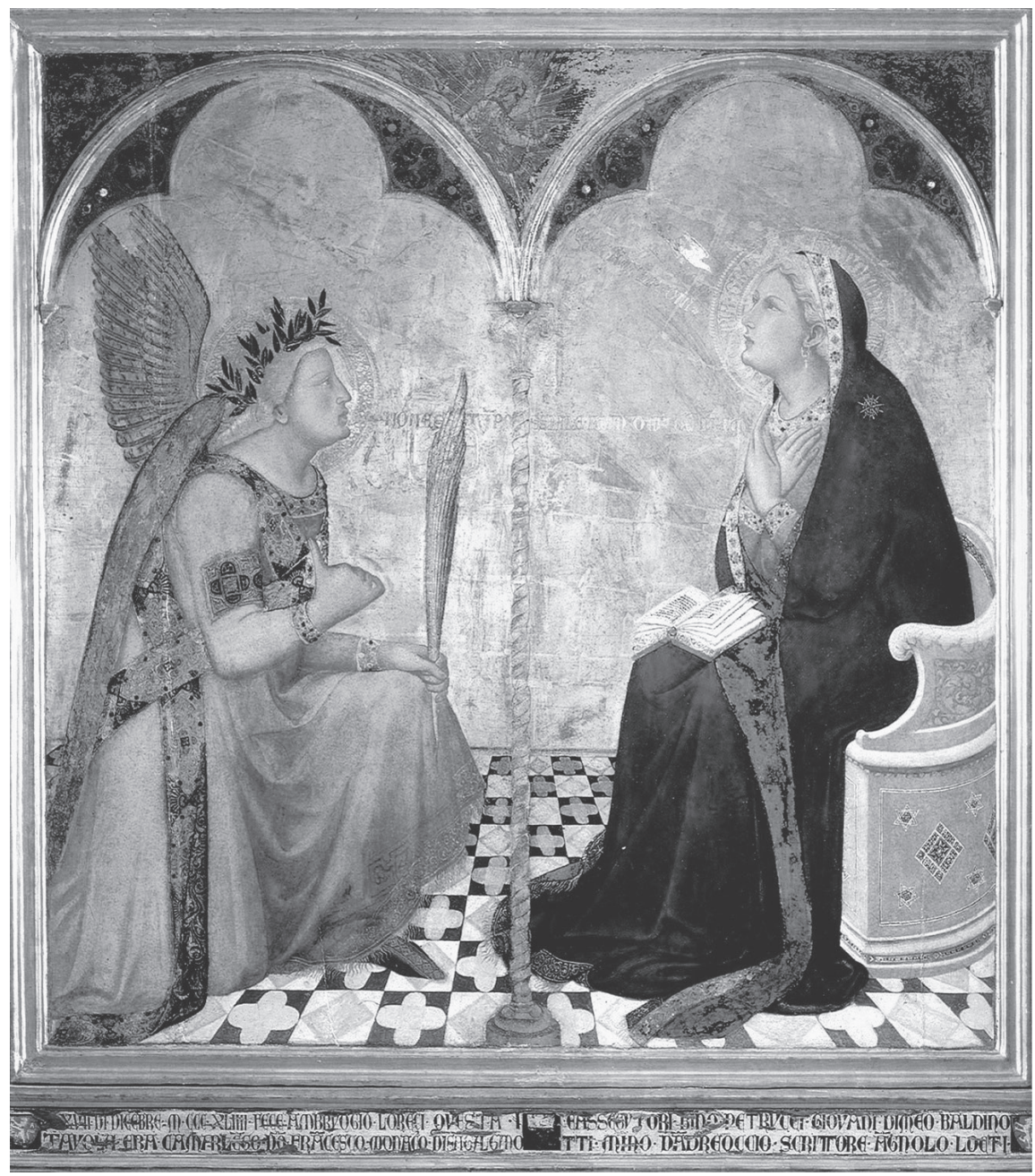

Fig. 5. Ambrogio Lorenzetti, La Anunciación, 1344. Pinacoteca Nazionale, Siena. Imagen tomada de Wikimedia Commons. Consultado el 30 de marzo de 2014. URL: http://commons. wikimedia.org/wiki/File:Lorenzetti_Ambrogio_annunciation-_1344..jpg?uselang=it

en torno al nimbo de la Virgen ${ }^{76}$, el ángel -portando ahora una palma (y no el clásico ramo de lirios o la sienesa rama de olivo) y apuntando con el pulgar hacia el cielo para indicar el origen divino de su embajada- explica a la doncella de qué modo, sin renunciar a su virginidad, Dios le permitirá ser Madre de su divino Hijo. Tal es la

\footnotetext{
${ }^{76}$ Esa es la frase allí inscrita, según puede apreciarse en detalles de esta tabla, incluidos en el repositorio de imágenes de Wimedia Commons: http://commons.wikimedia.org/wiki/Category:Annunciation_by_Ambrogio_ Lorenzetti [Acceso: 01/07/2015].
} 

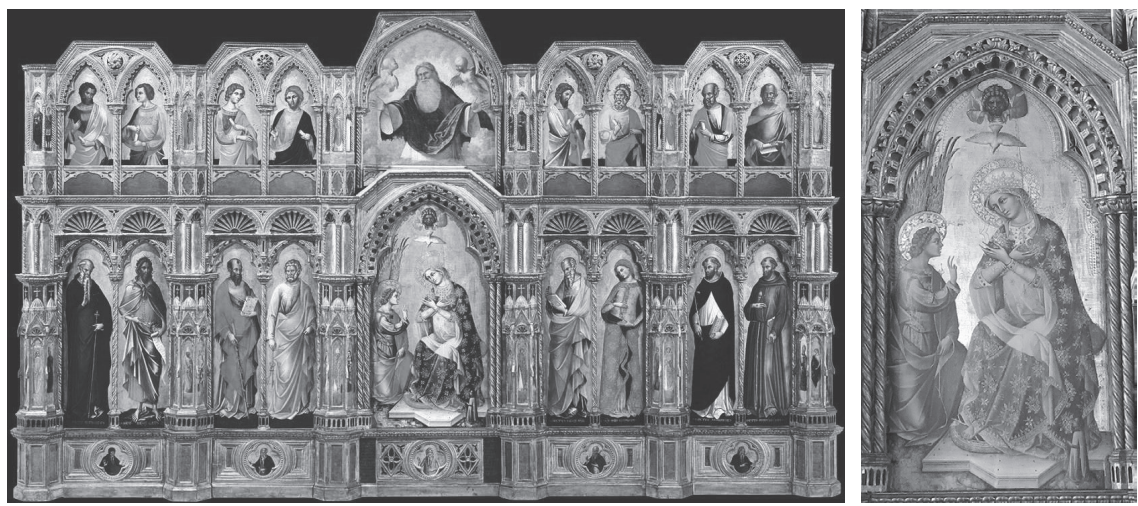

Fig. 6a. Lorenzo Veneziano, Políptico Lion, 1359. Gallerie dell'Accademia, Venecia. Imagen tomada de Wikimedia Commons. Consultado el 30 de marzo de 2014. URL: http:// commons.wikimedia.org/wiki/File:Lorenzo_veneziano,_polittico_lion_01.jpg?uselang=it

Fig. 6b. Lorenzo Veneziano, La Anunciación, panel central del Políptico Lion, 1359. Gallerie dell'Accademia, Venecia.

tranquilizadora garantía que Gabriel le transmite con la frase NON EST IMPOSSIBI$L E$ APUD DEUM O[MN]E V[ER]BUM ${ }^{77}$, la cual, saliendo de su boca, llega casi hasta la cabeza de María. Completando ese diálogo a tres, esta, levantando su rostro para mirar a Dios Padre en lo alto, le manifiesta su beneplácito mediante la frase $E C C E$ ANCILLA $D O\left[M I N I^{78}\right.$, que, fluyendo de sus labios, es recibida en forma directa por el Todopoderoso. Tras esa expresión de obediencia y asentimiento de la Virgen, el Altísimo envía hacia la oreja derecha de esta la blanca ave del Paráclito para fecundarla en ese mismo instante de su aceptación del designio divino.

Lorenzo Veneziano (act. 1356-1372 en Venecia), en La Anunciación del Políptico Lion, 1357, en las Gallerie dell'Accademia de Venecia (Figs. 6a y 6b) ${ }^{79}$, hace gala de cierta originalidad en el tratamiento del tema. En dicha escena mariana, motivo central de este complejo retablo ${ }^{80}$, el artista agrega algunas novedades a los previsibles elementos del modelo convencional. Convencionales son, en efecto las posturas del genuflexo arcángel apuntando con su diestra hacia arriba al momento de bendecir a la

77 Vale lo dicho en la precedente nota 76.

78 Véase la nota 76.

${ }^{79}$ Lorenzo Veneziano, La Anunciación del Políptico Lion, 1357, temple y oro sobre madera, 126 x 75 $\mathrm{cm}$, la tabla central inferior, y 121 x $60 \mathrm{~cm}$, cada uno de los cuatro paneles laterales inferiores; $82 \times 85 \mathrm{~cm}$, el panel central superior, y 67 × $60 \mathrm{~cm}$, cada uno de los cuatro paneles laterales superiores. Originalmente era el retablo del altar mayor de la iglesia de San Antonio Abad en Venecia, si bien hoy se halla en las Gallerie dell' Accademia de la misma ciudad.

${ }^{80}$ En el registro inferior, flanqueando la escena de la Anunciación, los paneles de la izquierda representan por parejas a los santos Antonio Abad y Juan el Bautista, y los apóstoles Pedro y Pablo; los paneles de la derecha plasman a los santos Juan Evangelista con María Magdalena, y Santo Domingo de Guzmán con San Francisco de Asís. El registro superior se completa con parejas de profetas, flanqueando a Dios Padre. 

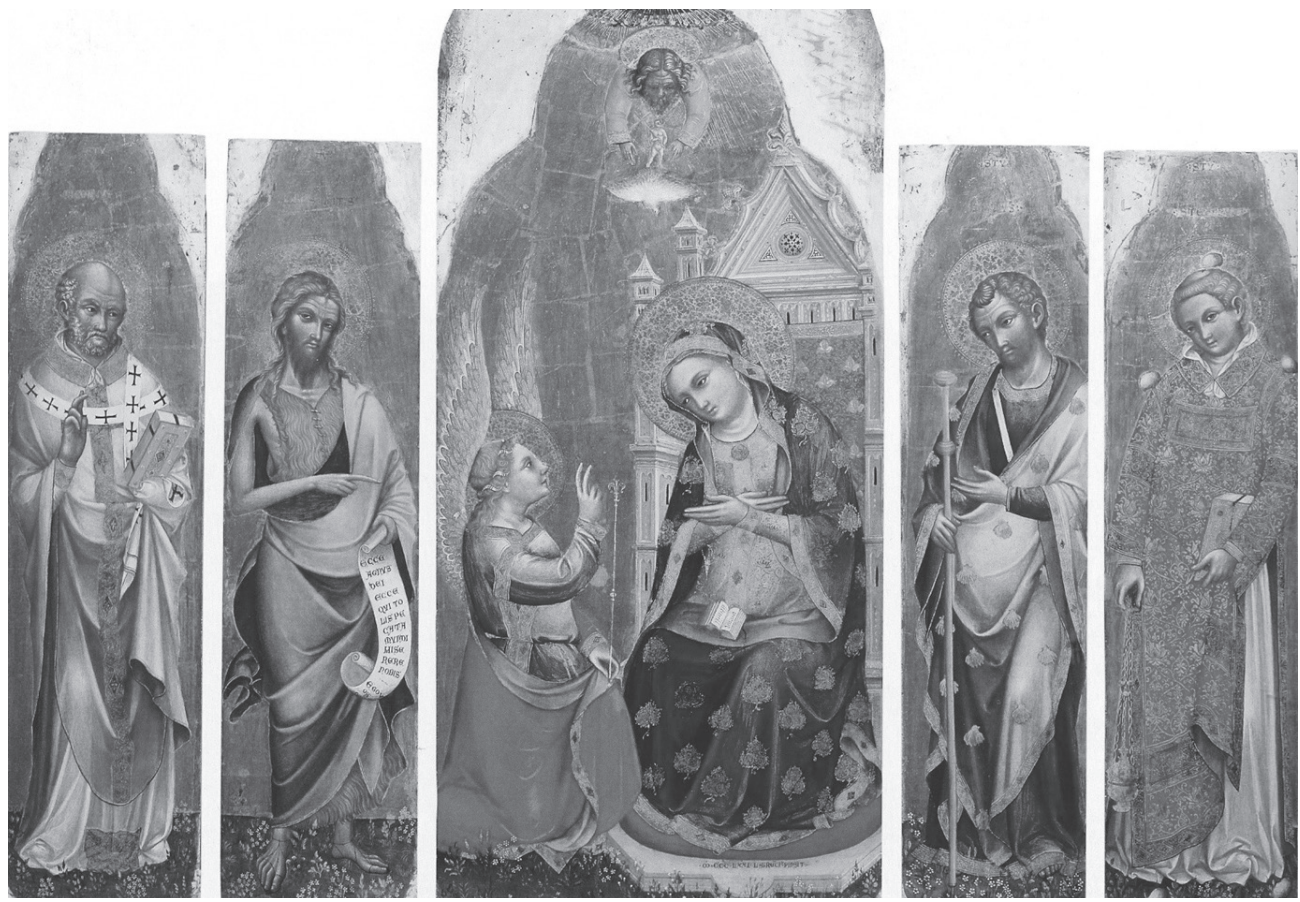

Fig. 7. Lorenzo Veneziano, Políptico de la Anunciación con santos, 1371. Gallerie dell'Accademia, Venecia. Imagen tomada de Wikimedia Commons. Consultado el 30 de marzo de 2014. URL: http://commons.wikimedia.org/wiki/File:9_Lorenzo_Veneziano, Annonciation_Polyptych._1371._Gallerie_dell\%27Accademia,_Venice.jpg?uselang=it

Virgen, quien, cabizbaja y con las manos cruzadas sobre el pecho, permanece sentada, teniendo a su vera al donante Domenico Lion, postrado de hinojos a escala diminuta. Pese a ello, dos novedades relevantes introduce aquí Lorenzo Veneziano: ante todo, el gesto de Dios Padre enviando o impulsando con ambas manos a la paloma del Espíritu Santo desde la vertical del eje compositivo, y no mediante la dirección oblicua usual en estos casos. Aún más importante es la novedad de que María, luego de recibir y aceptar el mensaje celeste, sugerido por el vuelo vertical del Paráclito hacia su oído derecho, exhibe un notorio embarazo en su vientre prominente, como señal de haber concebido ya por obra y gracia del Espíritu Santo y por la virtud del Altísimo que la está cubriendo con su sombra.

Lorenzo Veneziano, en el panel central del Políptico de la Anunciación con san$\operatorname{tos}^{81}$, 1371, en las Gallerie dell'Accademia de Venecia (Fig. 7) ${ }^{82}$, presenta ciertas

\footnotetext{
${ }^{81}$ Los santos son Gregorio Magno y Juan el Bautista en el registro de la izquierda, y Santiago el Mayor y Esteban, en el de la derecha.

${ }^{82}$ Lorenzo Veneziano, Políptico de la Anunciación con santos, 1371, temple y oro sobre madera, 111 x 54 $\mathrm{cm}$, la tabla central; y 94 x $24 \mathrm{~cm}$, cada uno de los cuatro paneles laterales. Gallerie dell'Accademia, Venecia.
} 
variantes sobre la estructura compositiva sustancial de su previo modelo en el Políptico Lion. Las poses de la Virgen y del arcángel, con su cayado o cetro florlisado, son casi identicas a las del cuadro precedente, como tambien lo son la manifiesta preñez de la Virgen y la disposición en vertical de Dios Padre en el acto de enviar con ambas manos la paloma del divino Espíritu sobre la cabeza de María, en el pleno eje de la composición. Tres novedades significativas introduce Lorenzo Veneziano en esta segunda versión del tema: ante todo, el ángel y la Virgen -sentada como una reina en lujoso trono- se sustentan sobre un parterre lleno de flores, para significar la

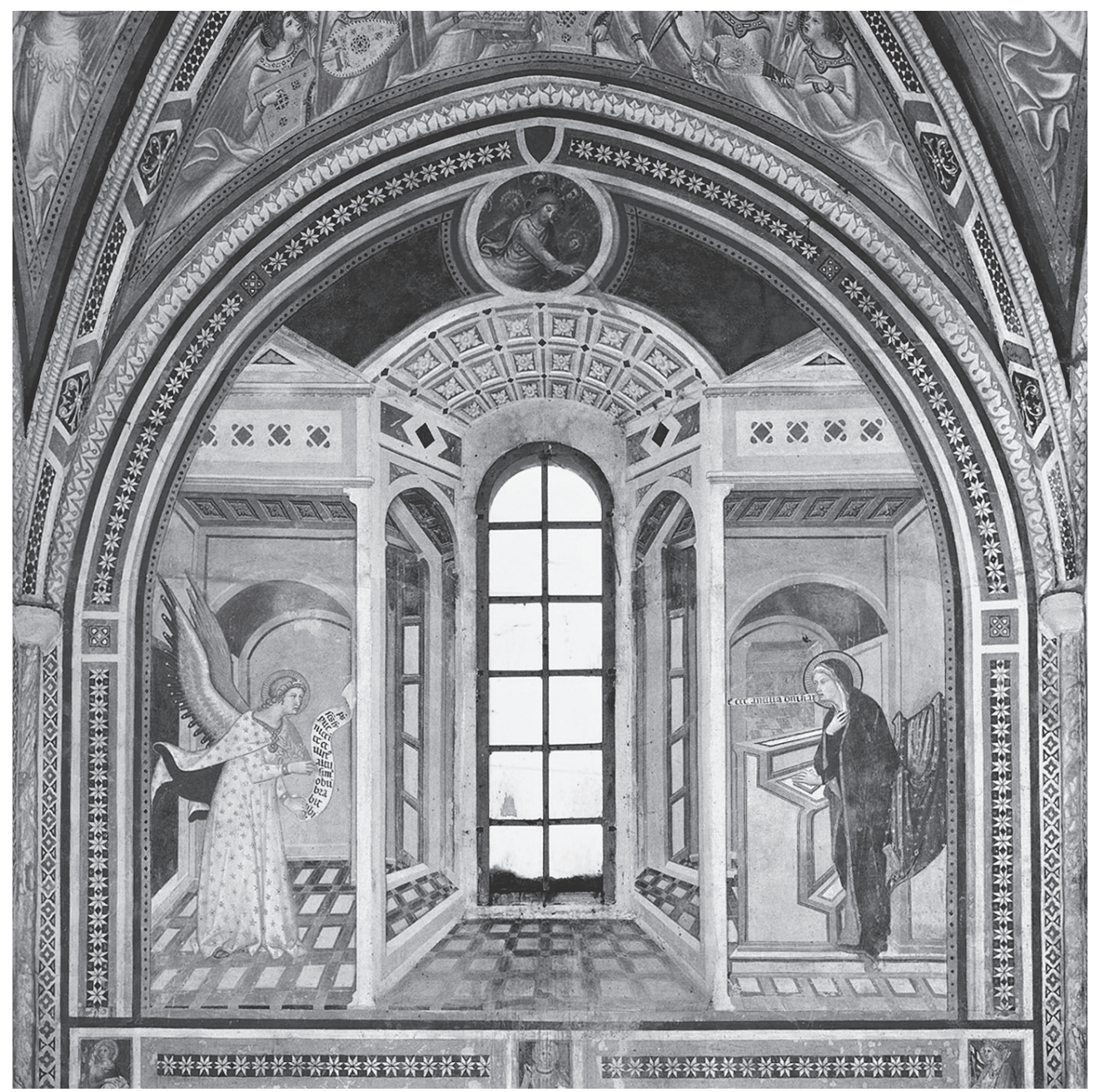

Fig. 8. Lippo Vanni. La Anunciación, c. 1360-70 (conjunto). San Leonardo al Lago, Siena. Imagen tomada de Flickr. Consultado el 30 de marzo de 2014. URL: https://www.flickr.com/ photos/24364447@N05/6559172521/sizes/o/in/photostream/ 
metáfora bíblica que alude a María como hortus conclusus; además, María mantiene abierto sobre su regazo -en una forma y ubicación harto significativas-el libro sacro, como para mejor visualizar que el Hijo de Dios encarnado que ya late en su vientre fue en reiteradas oportunidades preanunciado en los textos proféticos del Antiguo Testamento; en tercer lugar, Dios Hijo hecho carne aparece figurado en la cima, entre Dios Padre y el Espíritu Santo, como un minúsculo infante desnudo, para visibilizar su concepción en el seno de la Virgen, concepción que se hace efectiva en el instante mismo de su consentimiento a la propuesta del Altísimo. Mediante esa triple situación de las tres divinas Personas -en especial, la de Cristo bajo la figura de un fetosobre la cabeza de María, Lorenzo Veneziano ofrece una nueva y persuasiva versión de la conceptio per aurem.

Constreñido por la determinante ventana divisoria que ilumina la capilla, Lippo Vanni, en La Anunciación, ca. 1360-70, pintada al fresco en un luneto de la ermita sienesa de San Leonardo al Lago (Fig. 8) ${ }^{83}$, escinde la escena en dos bloques arquitectónicos. En el primero de ellos, correspondiente al vestíbulo de la residencia de María, sitúa al arcángel en postura erguida, desplegando una cimbreante filacteria con la consabida salutación congratulatoria inscrita en ella. En el segundo bloque, correspondiente a la alcoba de la Virgen, representa a esta poniéndose bruscamente de pie en su reclinatorio/escritorio, al ser sorprendida por la imprevista irrupción del mensajero celeste mientras meditaba ante el libro que mantiene abierto sobre la mesa. Estos bloques simétricamente contrapuestos -separados en hiato físico por el insalvable ventanal- resultan, pese a todo, íntimamente reunidos por Lippo Vanni como una sola unidad visual y narrativa mediante los siguientes recursos: la igualdad del diseño arquitectónico en ambos sectores de la escenografía, el triple pavimento de idénticas baldosas, la rebajada bóveda de artesones que cubre la galería hacia la ventana, la dialogante relación entre propuesta divina (inscripción en la filacteria) y asentimiento de la doncella (frase que sale de su boca) y, sobre todo, mediante la figura de Dios Padre que, en una circular «mandorla» o tondo, preside y controla el conjunto desde la cima del luneto. Es ahí donde un nuevo elemento concatenante se torna eficaz mediante la inclusión del divino hálito/rayo de vida que, emitido por el Altísimo y portando en su estela la paloma del Paráclito, penetra por la oreja derecha de la Virgen. Con ello se significa, una vez más, la efectiva concepción del Hijo de Dios hecho carne en el mismo instante en que su virginal madre está pronunciando su consentimiento al proyecto del Omnipotente con la humilde réplica ecce ancilla $d[$ omi]ni fiat, que luce inscrita emanando de su boca.

Taddeo di Bartolo ${ }^{84}$ (1362-1422), en su Políptico de la Anunciación, con los Santos Cosme y Damián, y Tránsito de la Virgen, 1409, en la Pinacoteca Nazionale de Sie$\mathrm{na}^{85}$ (Fig. 9), ofrece un diseño compositivo bastante convencional. De hinojos, el ángel

\footnotetext{
${ }^{83}$ Lippo Vanni. La Anunciación, c. 1360-1370, fresco. Ermita de San Leonardo al Lago, Monteriggioni (Siena).

${ }^{84}$ Sobre la obra de Taddeo di Bartolo véase el trabajo de Solberg 2002.

85 Taddeo di Bartolo, Poliptico de la Anunciación con los Santos Cosme y Damián, y Tránsito de la Virgen, 1409 , temple y oro sobre madera. Pinacoteca Nazionale, Siena.
} 


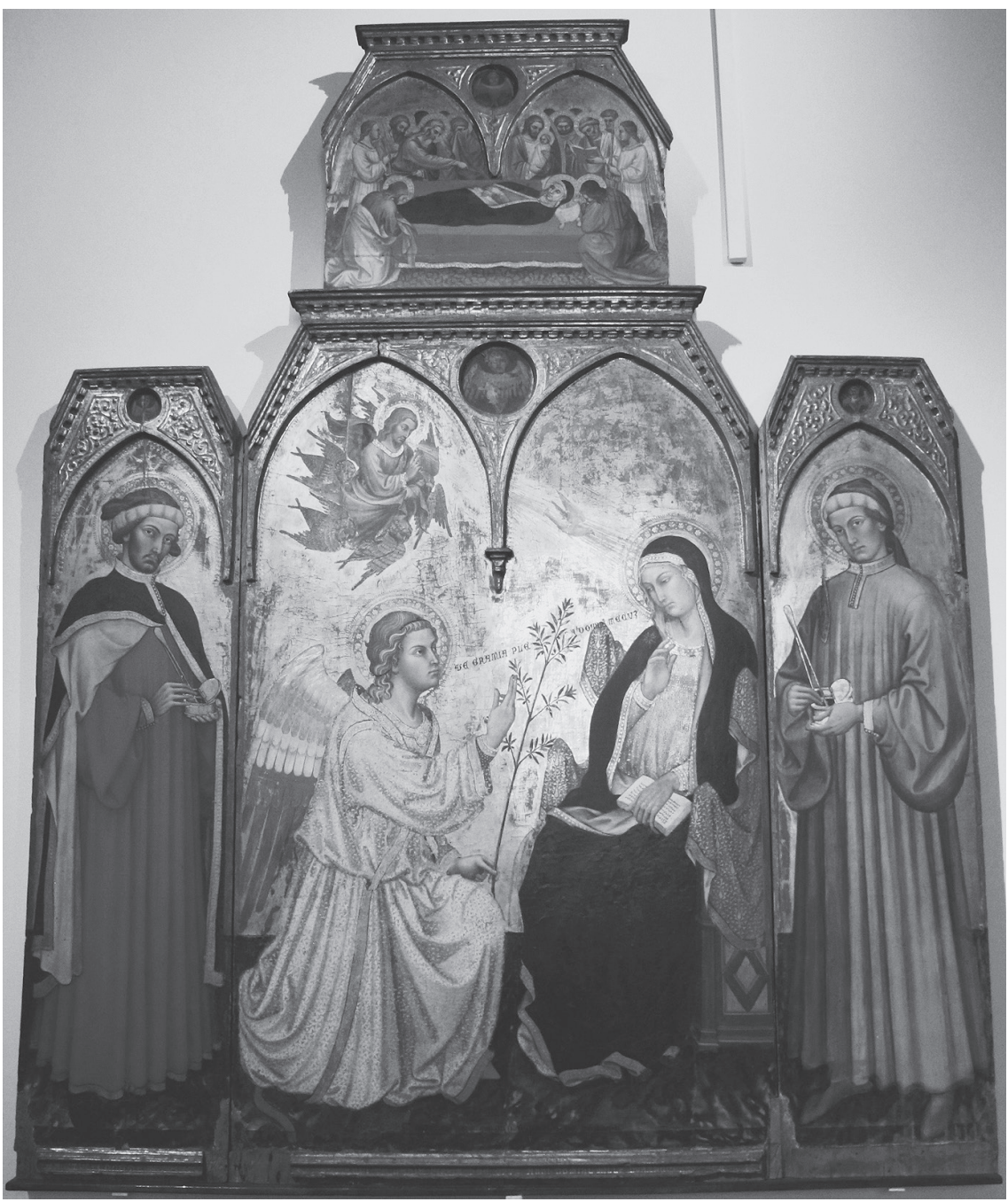

Fig. 9. Taddeo di Bartolo, Políptico con la Anunciación con los Santos Cosme y Damián, y Tránsito de la Virgen, 1409, Pinacoteca Nazionale, Siena. Imagen tomada de Wikimedia Commons. Consultado el 30 de marzo de 2014. URL: http://commons.wikimedia.org/wiki/ File:Taddeo_di_bartolo,_annunciazione.JPG?uselang=it

apunta hacia las alturas (el poder del Altísimo) al ofrecer un ramo de olivo a la Virgen, quien, cabizbaja y con el brazo derecho retraído con temor hacia su pecho, mantiene abierto sobre su regazo el libro, para simbolizar la inmediata concepción/encarnación del Mesías profetizada en las Escrituras. De medio cuerpo, esplendente desde su mandorla de querubines en la cúspide izquierda de la tabla, Dios Padre bendice a María enviando hacia ella el rayo de vida con la blanca ave del Espíritu divino. La novedad 
introducida aquí por Taddeo di Bartolo consiste en la redundancia de la que hace gala al visibilizar la conceptio per aurem. Esta, en efecto, viene significada por el doble recurso de hacer confluir hacia el oído derecho de la Virgen tanto el rayo de vida portador del Paráclito como el enalteciente saludo AVE GRATIA PLENA DOMINUS TECUM, que fluye de la boca de Gabriel. Al fin y al cabo, ese evidente pleonasmo visual patentiza el deseo del programador iconográfico de este retablo de asumir sin ambages -y con dos metáforas visuales complementarias- la tesis mariológica bajo examen.

\section{LA DOCTRINA DE LA CONCEPTIO PER AUREM EN LA TRADICIÓN PATRÍSTICA Y TEOLÓGICA}

La iconografía de la concepción por el oído, que con tanta claridad ilustran las nueve pinturas italianas aquí analizadas -como lo hacen asimismo otras muchas imágenes bajomedievales de la Anunciación en otros países de Europa, como Alemania, Flandes y España-, difícilmente podría explicarse si no se inspirara en una sólida tradición doctrinal que la «legitimase» con un sello de garantía cuasi-canónica. En este tercer apartado expondremos numerosas citas de algunos Padres de la Iglesia y teólogos medievales que contribuyeron de modo inequívoco a establecer y consolidar esta peculiar teoría mariológica.

Ya desde mediados del siglo IV, San Efrén de Siria (307-373) expresa en repetidas oportunidades la noción de la conceptio per aurem. Así, en un himno sobre la virginidad asegura sin rodeos que María, como una tierra sedienta, concibió al Señor por el oído (concepit ex auditu), motivo por el cual alaba sus oídos por haber ellos «bebido» la fuente (Jesucristo) que da de beber a todo el mundo ${ }^{86}$. En otro cántico en honor a la Iglesia, el mismo santo himnógrafo insiste en que «María hizo visible con su oído al Dios invisible, quien venía [a su oído] en la voz del ángel, de manera que el fruto de su vientre fue el Poder del Altísimo que vino a encarnarse» ${ }^{87}$. Y, en una exégesis sobre los Evangelios, San Efrén contrapone las actuaciones de Eva, «por cuyo oído entró la muerte» - al hacer caso a la engañosa palabra del demonio- y de María, «por cuyo oído entró la vida (per aurem intravit vita)», es decir, la redención del pecado, producida por el Hijo de Dios hecho carne en su seno. Por tal motivo, el santo sirio concluye que la deuda (el pecado original) contraída por el hombre (Adán) mediante un madero -el árbol de la ciencia del bien y del mal- sería solventada en el futuro por otro hombre (Cristo) mediante otro madero (la cruz) ${ }^{88}$.

\footnotetext{
86 «Maria, sitiens ager, in Nazareth Dominum nostrum concepit ex auditu. Tu quoque, mulier, aquam sitiens concepisti filium ex auditu. Beatae aures tuae, quae fontem suum biberunt, qui mundum potavit. Maria eum seminavit in praesepi; tu in auribus auditorum tuorum.» (San Efrén, De Virginitate 23. En Álvarez Campos 1970, vol. II, 505).

87 «Aure detexit Maria invisibilem Deum, qui veniebat in angeli voce; et fructus uteri sui Virtus fuit quae ad incarnationem venit.» (San Efrén, Hymni de Ecclesia 35. En Álvarez Campos 1970, vol. II, 509).

88 «Quia per aurem Evae intraverat mors, per aurem Mariae intravit vita. Et quia debita per lignum contraxerat homo, etiam ille, quando venit, per lignum solvit ea.» (San Efrén, Explan. Evang. Concord. 20, 32 En Álvarez Campos 1970, vol. II, 535).
} 
Más o menos por los mismos lustros San Zenón de Verona (ca. 300-371) establece con silogismos análogos una similar contraposición entre Eva y María, al señalar que, por cuanto el diablo produjo la muerte al vulnerar a Eva deslizándose por su oído mediante la persuasión, Cristo entró a encarnarse en María a través de su oído -per aurem intrat Christus in Mariam-, con el fin de eliminar todos los vicios presentes en el corazón de los humanos ${ }^{89}$. En otro tratado dogmático el mismo santo veronés expresa una idea similar, si bien con distinta figura analógica, al proclamar que el excelso vientre de María resplandece o da (a) luz (emicat), no por un don conyugal, sino por la fe; por el Verbo o Palabra de Dios, no por semen humano ${ }^{90}$.

En la primera mitad del siglo V San Proclo (ante 390-446), patriarca de Constantinopla, ${ }^{91}$ reitera con énfasis la tesis de la conceptio per aurem. Así en su primer sermón en alabanza a María, comienza por apuntar en líricos conceptos que ella, «esclava y madre, virgen y cielo, puente único de Dios hacia los hombres», es el instrumento elegido para tejer la encarnación, en el que, por una razón inefable, se confeccionó la túnica de $\mathrm{Cristo}^{92}$. Aprovechando al máximo las amplias posibilidades simbólicas de esa sugerente metáfora de la confección textil, enuncia luego que el tejedor de esa túnica (Jesucristo) es el Espíritu Santo, la hilandera es el poder del Altísimo que la cubrió con su sombra, la lana con la que se teje es el antiguo vellón de Adán, la trama es la carne inmaculada de la Virgen, el telar es la inmensa gracia de la gestante (María), y finalmente el artífice es el Verbo, que se desliza y penetra por el oído (artifex tandem, Verbum per auditum illabens). ${ }^{93}$ A partir de semejantes premisas el santo constantinopolitano se pregunta retóricamente quién ha visto u oído que Dios habite en un útero inviolado, y que aquel a quien los cielos no habían podido contener se aloje sin ningún problema en el estrecho vientre de la Virgen ${ }^{94}$.

Y en otro pasaje de ese mismo sermón, San Proclo se asombra de entrada ante el misterioso milagro mediante el cual el Emmanuel, por su condición de Dios, abrió las puertas de la naturaleza humana, al encarnarse en el seno de la Virgen María, sin

89 «Et quia suasione per aurem irrepens diabolus, Evam vulnerans interemerat; per aurem intrat Christus in Mariam, universa cordis desecat vitia: vulnusque mulieris, dum de virgine nascitur, curat». (San Zenón, Tract. XIII. De circumcis., X, 19-20. PL 11, 352).

90 «Etenim Deus Dei Filius, tempore constituto, dissimulata interim maiestate, ab aetherea sede profectus, in praedestinatae virginis templum sibimet castra metatur, quibus latenter infunditur in hominem gigniturus, ibidemque salvo quod erat meditatur esse, quod non erat. Mistus itaque humanae carni se fingit infantem. Mariae superbus emicat venter, non munere coniugali, sed fide, Verbo, non semine.» (San Zenón, Tract. VIII. De Nativ. Dom. II. PL 11, 413).

91 Sobre la doctrina teológica de San Proclo de Constantinopla, véase Constas 2003.

92 «Maria, inquam, ancilla et mater, virgo, ac coelum, Dei ad homines unicus pons, horrendum incarnationis textorium jugum, in quo ineffabili quadam ratione unionis illius tunica confecta est». (San Proclo, Oratio I. Laud. in sanct. Dei genitr. Mariam. PG 65, 682).

93 «cujus quidem textor exstitit Spiritus sanctus; nectrix, virtus obumbrans ex alto; lana, antiquum Adami vellus; trama, impolluta caro ex virgine; textorius radius, immensa gestantis gratia; artifex tandem, Verbum per auditum illabens.» (San Proclo, Oratio I. Laud. in sanct. Dei genitr. Mariam. PG 65, 682).

94 «Quis vidit, quis audivit, inhabitasse Deum in utero incircumscripte; ac eum quem coeli capere non poterant, nullis arctatum angustiis, ventrem Virginis comprehendisse?» (San Proclo, Oratio I. Laud. in sanct. Dei genitr. Mariam. PG 65, 682). 
violar ni romper la clausura de su virginidad ${ }^{95}$. Precisando aún más su razonamiento, proclama sin titubeos que el Hijo de Dios salió por el útero de la Virgen del mismo modo que entró en ella por el oído (ita ex utero est egressus, sicuti per aurem est ingressus), y nació de la misma manera con que fue concebido, pues ingresó en María sin comercio carnal (sine passione) y salió de ella sin perder su virginidad (egressus est absque ulla corruptione). ${ }^{96}$

En otra homilía sobre la Encarnación de Cristo, el mismo patriarca de Constantinopla, tras preguntarse cuándo la carne (la naturaleza humana) se unió substancial e inmutablemente a Dios ${ }^{97}$, brinda esta sugerente respuesta: ese prodigio sucedió cuando la Virgen María puso su útero a disposición de Dios, pues el Verbo se introdujo en ella a través del oído -Verbum autem per aurem insiliit-, mientras «el Espíritu Santo formaba un templo vivo, el Altísimo se rebajaba a la forma de siervo, y un útero gestaba conservándose virginal precisamente por ese misterio de una dispensa divina» ${ }^{98}$.

Y en un nuevo párrafo de una similar prédica sobre la Encarnación, San Proclo insiste en la idea de la conceptio per aurem al señalar que, si se atreviese a preguntar a la Virgen María cómo fue hecha Madre de Dios, de inmediato obtendría de ella la siguiente respuesta: «Un ángel incorrupto, no un marido, se atrevió poco ha a presentarse ante mí; y oí una palabra (verbum audivi), y concebí la Palabra o Verbo de Dios (verbum concepi), y entregué el Verbo divino a la Humanidad (verbum reddidi)» ${ }^{99}$.

En ese mismo siglo V el monje Fausto, obispo de Riez en Provenza (Faustus Reiensis, ca. 405/10-ca. 490/95), asegura que, después de dar María su asentimiento con el «Ecce ancilla Domini: fiat mihi secundum verbum tuum», el ángel regresó al cielo con esa aceptación verbal de la Virgen, y de repente el poder inefable del Altísimo penetró en sus entrañas ${ }^{100}$.

Hacia fines del siglo V o inicios del VI, el teólogo y vate siríaco Jacob de Sarug (ca. 451-521), expresa también en varias oportunidades, bajo fórmulas poéticas, la

95 «O mysterium! Miracula video, et Divinitatem praedico: passiones cerno, nec humanitatem inficior. Ceterum Emmanuel, naturae quidem portas aperuit ut homo; virginitatis autem claustra non violavit neque perrupit, ut Deus». (San Proclo, Oratio I. Laud. in sanct. Dei genitr. Mariam. PG 65, 691).

96 «quin ita ex utero est egressus, sicuti per aurem est ingressus: ita natus, sicut conceptus. Ingressus est sine passione; egressus est absque ulla corruptione». (San Proclo, Oratio I. Laud. in sanct. Dei genitr. Mariam. PG 65, 691).

${ }_{97}$ «Quandonam vero caro secundum substantiam Deo immutabiliter unita est, praeterquam heri?» (San Proclo, Oratio III. De Incarn. Dom. nostri Iesu Christi. PG 65, 707).

98 «quando sancta quidem Virgo suum uterum commodavit: Verbum autem per aurem insiliit; ac Spiritus Sanctus vivum efformavit templum; Altissimus in servi se formam exinanivit; ac demum divinae istud dispensationis mysterium uterus virginalis portavit.» (San Proclo, Oratio III. De Incarn. Dom. nostri Iesu Christi. PG 65, 707).

99 «Si autem et ipsam Deiparam interrogare auderem quomodo facta sit mater sine coniugio, prorsus respondebit: "Angelus nuper incorruptus, non maritus, ausus est adstare; et verbum audivi, verbum concepi, verbum reddidi”.» (San Proclo, Hom. de Incarn. Dom. En Álvarez Campos 1976, vol. IV/1, 71).

100 «At illa inquit: "Ecce ancilla Domini sum: fiat mihi secundum verbum tuum (Lc. 1, 38)". Mox igitur angelus virginis accepto consensu coelestis regionis incolas repetivit; et ecce subito secretum virginis ineffabilis potentia penetravit.» (Faustus Reiensis, Sermo 2. En Álvarez Campos 1981, vol. VI, 106). 
tesis de la conceptio per aurem. ${ }^{101}$ Por ejemplo, en un sermón en verso sobre la Anunciación, subraya -en clave de ambivalentes analogías- la diferencia de origen y naturaleza entre el Hijo de Dios encarnado y la Virgen, al exponer sobre aquel fecundador anuncio celestial:

Fuera de la oreja [de María] se coloca la voz [del angel] y avanza con premura el Verbo [de Dios], pues es conocido el lugar de la voz de donde ella llega.

No sale de la mente [del ángel] cuando aquel Verbo es enviado, ni penetra simultáneamente en el oído cuando aparece el Verbo. Entre la boca [del ángel] y el oído [de María] está su ministro: a dondequiera que el Verbo viene o va ella no tiene acceso ${ }^{102}$.

Y en otra homilía versificada en honor de la fiesta de la Visitación de María a su prima Isabel, el Sarugense elabora una nueva formulación poética de la tesis en examen, al señalar:

Se esconde [Cristo] en la mente y sin cópula habita en el alma [de María], y la unión carnal no puede obtenerlo [el Verbo].

Y por eso el Verbo eligió para sí una virgen, ajena a toda relación conyugal, para nacer corporalmente de ella;

y emitió una Voz, concebida mediante convenio, para que preparase el camino y allanase la senda mientras él mismo se manifesta$\mathrm{se}^{103}$

A renglón seguido, el homilista de Sarug continúa su metafórica exégesis sobre la encarnación de Jesús por la oreja de la Virgen mediante estos ingeniosos circunloquios:

101 Mientras el presente artículo se hallaba en proceso de evaluación en ILU. Revista de Ciencias de las Religiones, tuvimos la oportunidad de publicar en otra revista un amplio estudio exclusivamente focalizado en la doctrina de Jacob de Sarug sobre la conceptio per aurem. (Véase Salvador González 2014, 96-130).

102 «Extra aurem vox consistit verbumque procurrit, notus enim est vocis locus quo ea pervenit.

Non exit a mente cum illud mittitur, nec simul penetrat auditum cum Verbum apparet.

Inter os auditumque suus est minister: quocumque venit vel vadit Verbum illa non accedit.» (Jacob de Sarug, Hom. de Mariae visit. En Álvarez Campos 1981, vol. V, 48).

103 «Absconditur in mente et sine copula habitat in anima, nec potest ad illud coniunctio accedere.

Ideoque virginem, quae aliena erat a coniunctione, sibi delegit Verbum, ut corporaliter ex ea nasceretur; et misit Vocem, quae fuit per coniunctionem concepta, ut ordinaret viam complanaretque semitam dum ipse se monstraret.

(Jacob de Sarug, Hom. de Mariae visit. En Álvarez Campos 1981, vol. V, 48). 
También la voz [del ángel] que va hacia el oído precede al Verbo, y aquella lanza a este para que, entrando el Verbo [por la oreja de María], abra la puerta.

El anuncio del Verbo conduce la Voz [del ángel] a la puerta de los oídos para que anteceda a Aquel y por ella [la voz del ángel] prepare el oído.

[La voz] Penetra el aire y allana la vía para que [el Verbo] corra; y apenas llega aquella a la puerta del oído y se detiene, el Verbo penetra [por él] ${ }^{104}$.

Y, en una carta dirigida a unos monjes, Jacob de Sarug replantea mediante otras figuras analógicas la doctrina de la conceptio per aurem. En efecto, tras comparar al anunciador arcángel Gabriel con una perla que, colgando de las orejas de las doncellas, honra sus oídos, afirma que la Virgen es digna de recibir esa perla que es el Verbo divino, enviado por Dios Padre como prenda y salvador del mundo ${ }^{105}$. El poeta siríaco llega incluso a comparar al precursor mensajero celeste con una puerta, poniendo en su boca estos expresivos símiles:

A semejanza de la puerta en la que se manifiesta la luz, yo estoy colgado en las orejas de las doncellas, para honrar el oído que fue la puerta del Verbo divino que quiso habitar en aquella muchacha [María]. A semejanza de un portero, soy colocado en la puerta de las orejas, para honrar al oído habitado por el Verbo. (...) Corrí hacia el oído, y abrí la puerta ante él ${ }^{106}$.

También hacia el siglo VI un himnógrafo anónimo se adhiere a la defensa de esta creencia, al enunciar que Cristo «entró a través del oído de María y habitó en secreto su útero, y que luego al salir de él en su nacimiento no rompió los sellos virginales [el himen], como tampoco rompió los sellos del sepulcro al salir resucitado» ${ }^{107}$.

Tal vez por los mismos decenios Isaac de Antioquía no duda en suscribir también la tesis de la conceptio per aurem. En su Tercer Sermón, en efecto, sostiene que Cristo

104 «Vox etiam ad auditum praecedit verbum,

et illum excutit ut verbo aperiat portam intranti.

Notitia Verbi Vocem ducit ad aurium portam

ut praecurrat illi et per eam praeparet auditum.

Findit aerem complanatque viam ut currat;

et vix pervenit ad ianuam auris quiescitque, penetrat Verbum.» (Jacob de Sarug, Hom. de Mariae visit. En Álvarez Campos 1981, vol. V, 48).

105 «Ego margarita ab auribus suspendor, ut auditum honorem puellarum; quia sunt dignatae margaritam accipere, Verbum nimirum a Patre demissum ut pignus et salvatorem mundi.» (Jacob de Sarug, Epist. ad mon. Conv. Mar Bassus, 15. En Álvarez Campos 1981, vol. V, 92).

106 «Ego, similis portae in qua depingeretur lumen, in auribus suspendor puellarum; ut honorem aurem quae Verbi porta fuit in puella habitare volentis. Ianitoris instar sistor in auris ostio, ut aurem quam Verbum habitavit honorem. (...) Cucurri ad aurem, et ostium ante eum aperui.» (Jacob de Sarug, Epist. ad mon. Conv. Mar Bassus, 15. En Álvarez Campos 1981, vol. V, 92).

107 «Ingressus est per aurem et secreto uterum inhabitavit; e ventre porro exiens, non solvit sigilla virginalia, sicut nec solvit exeundo sigilla sepulcri.» (Himnógrafo anónimo, Hymnus 11. En Álvarez Campos 1981, vol. $\mathrm{V}, 170)$. 
no perdió su majestad divina al descender del trono celestial al vientre de la Virgen, ni perdió su divinidad al revestirse de humanidad, con la aclaratoria adicional de que vino sin cuerpo a María, y no nació de ella solo con la carne o con una sola naturaleza (la humana), sino que una sola naturaleza (la divina) entró en la Virgen y de esta salieron dos naturalezas (divina y humana) ${ }^{108}$. El pensador sirio insiste todavía en esa dualidad de naturaleza de Jesús, al concluir: «Entró en María una sola naturaleza divina, y salieron dos naturalezas encarnadas en él. Sin estar aún encarnado entró por el oído, y salió ya encarnado» ${ }^{109}$.

Y en su Cántico Sexto el mismo Isaac de Antioquía remacha esos mismos conceptos, al proclamar que Jesucristo «entró como espíritu divino a través del oído de la Virgen, y salió de su vientre como carne humana», pues, como bien se conoce, el Ser puramente espiritual se hizo corpóreo (encarnado), o, dicho en otros términos, el Ser puramente espiritual descendió sin cuerpo a María, y nació del seno de esta encarnado como hombre ${ }^{110}$.

Llegados a este punto en nuestro discurso, resulta necesario puntualizar que hasta el siglo VI los escritores que sostienen la noción mariológica en estudio mencionan de manera explícita la fórmula de la conceptio per aurem -si bien, a nuestro juicio, sin considerarla como un verdadero acto físico ${ }^{111}$, mientras los teólogos posteriores a dicha centuria formulan tal noción en un sentido laxo, de mayor sutilidad simbólica. Como veremos en seguida, los autores cristianos posteriores al siglo VI se refieren al oído de María en la Anunciación no como un canal genésico por el que habría pasado material y físiológicamente el hálito/fluido fecundador de Dios Padre/Espíritu Santo, ni menos aún el propio Dios Hijo ya encarnado, sino como el canal acústico por el que la Virgen recibió inmaterialmente el mensaje (la Palabra) de Dios Padre, que le proponía la concepción/encarnación de la Palabra (Logos o Verbo) de Dios Hijo en su vientre sin perder su virginidad. Por tal motivo, todos esos escritores sacros desde el siglo VI en adelante pondrán énfasis en la Palabra emitida por el Altísimo, más bien que en el oído de María como presunto conducto genésico.

En esa nueva línea exegética se sitúa incluso un escritor activo aún en el período precedente: cierto anónimo conocido como el Pseudo Agustín, fecha-

\footnotetext{
108 «Nulla erat contumelia maiestati eius quod de throno ad ventrem descendit, nec divinitatem perdidit cum humanitatem indueretur. Non in corpore venit ad Mariam, nec sola caro nata est; non una natura nata est, sed una intravit et duae egressae sunt.» (Isaac de Antioquía, Sermo 3. En Álvarez Campos 1981, vol. V, 183).

109 «Intravit ad eam una de coelo, et egredi faciebat duas in carne illius. Non incarnatus intravit per aurem, et egredi faciebat incarnatum.» (Isaac de Antioquía, Sermo 3. En Álvarez Campos 1981, vol. V, 183).

110 «Per aurem enim spiritus intravit, et ex ventre caro egressa est. Ecce notum et apertum est spiritualem illum corporeum factum esse. Corpus non secus adduxit, sed venit ut corporeus fieret. Spiritualis descendit ad Mariam, et homo de sinu eius ortus est.» (Isaac de Antioquía, Carmen 6. En Álvarez Campos 1981, vol. V, 184).

111 Pese a que esos primeros pensadores cristianos parecerían, a primera vista, formular sus propuestas sobre la conceptio per aurem en el sentido literal de que el oído de la Virgen habría sido el conducto físico por el que se habría verificado la «inseminación» o impregnación de su vientre por el poder de Dios, creemos que todos ellos interpretan ese prodigio según la siguiente digresión metafórica: el oído sería, de manera simple y natural, el conducto que permitió a María escuchar el mensaje celestial proponiéndole la concepción virginal del Verbo de Dios en su vientre, y que, tras la escucha, le facilitó verbalizar su consentimiento ante la propuesta del Altísimo.
} 
ble entre los siglos V y VI. En un sermón sobre la Natividad de Jesús, dicho autor asegura que María no parió como las demás mujeres, pues engendró a un hijo sin dejar de ser virgen, y mereció gestar a la misma divinidad: tan excepcional fenómeno sucedió conforme a la promesa contenida en el mensaje del ángel de que «el Espíritu Santo vendrá sobre ti y el poder del Altísimo te cubrirá con su sombra», como consecuencia de lo cual su vientre se convirtió en el palacio del Espíritu Santo ${ }^{112}$. A juicio del Pseudo Agustín, María, tras oír el pacto propuesto por Dios y prestar oído a su mensajero celestial, manifestó su consentimiento con aquel Ecce ancilla Domini; fiat mihi secundum verbum tuum, que le mereció de inmediato tener hospedado a Dios en la cámara de su vientre, hasta el punto de llenarse el ámbito de su útero y de quedar encerrada toda la infinita majestad divina dentro de los estrechos límites de un cuerpo humano ${ }^{113}$.

Medio milenio más tarde el cardenal benedictino San Pedro Damián (1007-1072) expresa a su modo la teoría de que la concepción/encarnación de Cristo en el seno de la Virgen se verificó en el mismo instante en que esta escuchó y aceptó la promesa del Altísimo de que conservaría intacta su virginidad al concebir y alumbrar al Hijo de Dios hecho hombre. Así en una prédica sobre la Anunciación, luego de expresar que el arcángel Gabriel recibió del Señor un mensaje que contenía «un saludo a María, la encarnación del Redentor, la plenitud de la gracia, la grandeza de la gloria y la multitud de la alegría» ${ }^{114}$, el santo asegura sin embozos que la Virgen, después de que le hablara el arcángel Gabriel, «sintió a Dios deslizado en sus entrañas, así como la infinita majestad de aquel encerrada en el breve espacio del vientre virginal» ${ }^{115}$.

Casi una centuria más tarde San Bernardo de Claraval (1090-1153) asume también -si bien mediante ingeniosas metáforas, desde su típica grandilocuencia- la figura retórica de la conceptio per aurem. En su cuarto sermón en honor a María, por ejemplo, diseña una alambicada fantasía para destacar la humilde disponibilidad de la Virgen al aceptar -con la fórmula Ecce ancilla Domini, fiat mihi secundum verbum tuum $^{116}$ - la oferta divina de convertirse en virginal madre del Hijo de Dios. Así comienza enunciando el Claravalense la tesis analizada:

\footnotetext{
112 «Non ita, Maria; non sic paries quomodo ceterae feminae. Tu ita filium generabis, ut nunquam amittas castitatem, quae ipsam portare mereberis deitatem. "Spiritus sanctus superveniet in te, et virtus Altissimi obumbrabit tibi (Lc. 1, 35)". Quia venter tuus palatium factus est Spiritus Sancti.» (Pseudo-Augustinus, In Nat. Dom., 2. En Álvarez Campos 1981, vol. VI, 269).

113 «Et illa, ubi coeleste audivit pactum, nuntio praebet auditum, et meruit illico intra cameram ventris habere hospitem Deum. "Ecce", inquit, "ancilla Domini; fiat mihi secundum verbum tuum (Lc. 1, 38)". Repletur ambitus uteri; concluditur intra humani corporis metas tota maiestas.» (Pseudo-Augustinus, In Nat. Dom., 2. En Álvarez Campos 1981, vol. VI, 269).

114 «Traditur epistola Gabrieli, in qua salutatio Virginis, incarnatio Redemptoris, modus redemptionis, plenitudo gratiae, gloriae magnitudo, multitudo laetitiae continetur.» (San Pedro Damián, Sermo XI. De Annun. Beat. Virg. Mariae. PL 144, 558).

115 «Missus est ergo angelus Gabriel a Deo ad Virginem, quae, postquam ei locutus est, sensit Deum suis illapsum visceribus, majestatemque illius virginalis ventris brevitate conclusam,» (Ibid.).

${ }^{116}$ Lc 1, 38. En Biblia Sacra 2005리 1011.
} 
Esto lo comprendió muy bien aquella Virgen prudente cuando, al don anticipado por una promesa, supo unir el mérito de su oración diciendo: Hágase en mí según tu palabra. Hágase en mí por el Verbo según tu promesa. Hágase carne de mi carne según tu palabra, la Palabra que ya existía al principio en Dios ${ }^{117}$.

Según el artificioso libreto imaginado por San Bernardo, María continúa su asentimiento a la oferta del Altísimo con esta hiperbólica súplica:

Te suplico que se cumpla en mí la Palabra; pero no declamada, porque pasa; sino concebida, para que permanezca. Revestida, pero no de aire, sino de carne. Hágase en mí tu palabra, no solo porque pueda escucharla en los oídos, sino tocarla con mis manos, contemplarla con los ojos y llevarla a cuestas. No se haga en mí la palabra escrita y muda, sino encarnada y viva. No trazada con caracteres sin voz sobre pergaminos resecos, sino impresa vitalmente en forma humana sobre mis castas entrañas; no por los rasgos de una pluma, sino por obra del Espíritu Santo. En definitiva, hágase en mí como nunca se hizo en nadie antes de mí y como en nadie se volverá a realizar ${ }^{118}$.

A renglón seguido, el abad de Claraval, imagina a la Virgen profiriendo esta imaginaria solicitud para pedir al Señor la concreción física de su prometido Verbo de Dios encarnado:

En múltiples ocasiones y de muchas maneras habló Dios antiguamente a nuestros padres por los profetas. Nos dicen las Escrituras que unos escucharon la Palabra, otros la proclamaron y otros la cumplieron; pero yo te pido que se haga en mi vientre según tu Palabra ${ }^{119}$.

Y en un nuevo circunloquio San Bernardo pone en boca de María estas solemnes expresiones, pidiendo a Dios que en su seno virginal se haga efectiva la concepción/ encarnación de la Palabra divina que le prometió por intermedio del arcángel Gabriel:

\footnotetext{
117 «Hoc utique prudens Virgo intellexit, quando praevenienti se muneri gratuitae promissionis, iunxit meritum suae orationis: Fiat, inquiens, mihi secundum verbum tuum. Fiat mihi de Verbo secundum verbum tuum. Verbum, quod erat in principio apud Deum». (San Bernardo, In laud. Virg. Matris. Homilia IV, 11. 1984, 676).

118 «fiat caro de carne mea secundum verbum tuum. Fiat, obsecro, mihi Verbum, non prolatum quod transeat, sed conceptum ut maneat, carne videlicet indutum, non aere. Fiat mihi non tantum audibile auribus, sed et visibile oculis, palpabile manibus, gestabile humeris. Nec fiat mihi verbum scriptum et mutum, sed incarnatum et vivum, hoc est non mutis figuris, mortuis in pellibus exaratum, sed in forma humana meis castis visceribus vivaciter impressum, et hoc non mortui calami depictione, sed Spiritus Sancti operatione. Eo videlicet modo fiat mihi, quo nemini ante me factum est, nemini post me faciendum.» (San Bernardo, In laud. Virg. Matris. Homilia IV, 11. 1984, 676s).

119 «Porro multifariam multisque modis olim Deus locutus est Patribus in Prophetis: et aliis quidem in aure, aliis in ore, aliis etiam in manu factum esse verbum Domini memoratur; mihi autem oro, ut et in utero fiat iuxta verbum tuum.» (San Bernardo, In laud. Virg. Matris. Homilia IV, 11. 1984, 678).
} 
Y no quiero que [la Palabra] se haga en mí como una proclamación declamada, o como una señal figurativa, ni como un sueño imaginario, sino aspirándola en silencio, como una encarnación personal poseída corporalmente en mis entrañas. En fin, el Verbo, que ni pudo encarnarse en sí mismo ni lo necesitaba, dígnese hacerse carne en mí y también para mí, según tu Palabra. Hágase, por tanto, universalmente para todo el mundo y particularmente hágase para mí según tu palabra ${ }^{120}$.

Queda así puesta en relieve una parte significativa de los múltiples y concordantes textos de Padres de la Iglesia y teólogos medievales que -bajo la forma de una afirmación apodíctica o, con mayor frecuencia, bajo la modalidad de una blanda metáfora simbólica- suscriben la teoría de la conceptio per aurem. Por si fuera poco, junto a esa canónica tradición patrística y teológica, algunos escritos apócrifos reflejan también la misma tesis ${ }^{121}$. Así lo manifiesta hacia el siglo VI el Evangelio armenio de la Infancia, al describir así la conclusión del largo diálogo que Gabriel entabló con María:

Dícele el ángel: «¡Oh santa y dichosa Virgen! Escucha esta palabra y retén bien en tu alma lo que voy a decirte. Esto no es obra de hombre, y el acontecimiento de que te hablo no será provocado por él. Es Dios quien lo realizará en ti. Él tiene en sus manos poder suficiente para librarte de todas las angustias de la prueba». María responde: «Si es tal como dices y el Señor tiene a bien bajar hasta su sierva y esclava, hágase en mí según tu palabra». Y el ángel se retiró. ${ }^{122}$

El relato apócrifo continúa a reglón seguido en estos términos:

No bien hubo pronunciado la Virgen con toda humildad estas palabras, el Verbo de Dios penetró en ella por la oreja ${ }^{123}$, y la naturaleza íntima de su cuerpo, con todos sus sentidos, fue santificada y purificada como el oro en el crisol. Quedó convertida en un templo santo, inmaculado, mansión del Verbo divino. Y en el mismo momento dio comienzo el embarazo de la Virgen ${ }^{124}$.

A su vez, la fantasiosa Vita Virginis («biografía» apócrifa fechable hacia el siglo VII) asume la misma idea, pese a repetir casi al pie de la letra el texto del Evangelio de San Lucas sobre la Anunciación. Al relatar este acontecimiento, dicho apócrifo

120 «Nolo ut fiat mihi aut declamatorie praedicatum, aut figuraliter significatum, aut imaginatorie sommatum, sed silenter inspiratum, personaliter incarnatum, corporaliter invisceratum. Verbum igitur, quod in se nec poterat fieri, nec indigebat, dignetur in me, dignetur et mihi fieri secundum verbum tuum. Fiat quidem generaliter omni mundo, sed specialiter fiat mihi secundum verbum tuum.» (San Bernardo, In laud. Virg. Matris. Homilia IV, 11. 1984, 678).

${ }^{121}$ Es bien probable que los dos textos apócrifos que mencionaremos a continuación (el uno de hacia el siglo VI, el otro de la centuria siguiente) hayan asumido la tesis de la conceptio per aurem inspirándose directamente en los textos canónicos de algunos Padres de la Iglesia.

122 Evangelio Armenio de la Infancia, 8. En Santos Otero 2006, 353s.

123 Énfasis del autor.

124 Evang. Armen. Inf., 9. En Santos Otero 2006, 354. 
asevera que la Virgen -cuando, tras oír del ángel la promesa divina de que conservaría su virginidad al convertirse en madre, dio su consentimiento con el Ecce ancilla Domini; fiat mihi secundum verbum tuum - «concibió inmediatamente por el oído (Ceterum ipsa concepit ex auditu)», y luego permaneció tres meses junto a José, al estar ya grávida del Hijo de Dios vivo ${ }^{125}$.

No resulta, por lo demás, nada desdeñable al respecto el aporte -por esporádico y relativo que parezca- ofrecido también por la liturgia. En ese orden de ideas, un himno del siglo XII, ${ }^{126}$ que forma parte del conjunto de la anónima pieza laudatoria Septem gaudia Mariae ${ }^{127}$, pregona en su primera estrofa:

\author{
Gaude virgo, mater Christi, \\ quae per aurem concepisti \\ Gabriele nuntio: \\ gaude, quia Deo plena \\ peperisti sine poena \\ cum pudoris lilio $^{128}$.
}

Y en sus dos siguientes estrofas, ese himno mariano expresa:

\author{
Gaude, quia tui nati, \\ quem dolebas mortem pati, \\ fulget resurrectio: \\ gaude Christo ascendente \\ in coelum, qui te vidente \\ motu fertur proprio. \\ Gaude, quae post Christum scandis \\ et est honor tibi grandis \\ in coeli palatio, \\ ubi fructus ventris tui \\ per te detur nobis frui \\ in perenni gaudio. ${ }^{129}$
}

\footnotetext{
125 «Cui respondit angelus: "Spiritus Sanctus superveniet in te et virtus Altissimi obumbrabit tibi; ideoque et quod nascetur sanctum vocabitur Filius Dei (Lc, 1,35)". Haec autem audiens Virgo ait: "Ecce ancilla Domini; fiat mihi secundum verbum tuum. Et discessit ab ea angelus (Lc. 1,38)". Ceterum ipsa concepit ex auditu; et etiam menses tres apud Iosephum permansit, cum esset Filio viventis Dei gravida.» (Vita Virginis. En Álvarez Campos 1981, vol. V, 236s).

126 Este anónimo himno litúrgico Gaude virgo, mater Christi del siglo XII ha sido atribuido, sin mayor fundamento documental, a Santo Tomás Becket, e incluso a San Buenaventura (quien es ya del s. XIII).

127 Este himno latino fue transcrito en su versión original y puesto en paralelo con su traducción literal al inglés antiguo en el manuscrito Glade us, maiden, moder milde. Index no. 912. MS: Trinity College Cambridge 323 (B.14.39) fols. 28b-29a (c. 1250). Edition: B13 no. 22. http://www.lib.rochester.edu/camelot/ teams/picofnts.htm [Acceso: 05/07/2015].

128 MS: Trinity College Cambridge 323 (B.14.39) fols. 28b-29a (c. 1250). Edition: B13 no. 22.

129 MS: Trinity College Cambridge 323 (B.14.39) fols. 28b-29a (c. 1250). Edition: B13 no. 22.
} 


\section{CONCLUSIÓN}

Podríamos sintetizar los principales resultados de nuestra investigación en estos breves párrafos:

Sorprende, de entrada, el escaso interés de los especialistas por documentar con rigurosa precisión e interpretar a cabalidad mediante fuentes primarias la antaño difundida tesis mariológica de la conceptio per aurem, según la cual la encarnación del Hijo de Dios se habría efectuado de algún modo a través del oído de María.

Pese a tan sorprendente desinterés u omisión por parte de la mayoría de los expertos, una investigación a fondo revela pronto que esa tesis tuvo un enorme predicamento en el arte y el pensamiento cristianos durante la Tardoantigüedad y la Edad Media.

El tema se encuentra, en verdad, ilustrado con amplitud y claridad en numerosas obras artísticas de la Europa medieval, de entre las que analizamos aquí nueve representaciones paradigmáticas en la pintura italiana del Trecento.

Respecto a las fuentes literarias, se documenta asimismo una abundante serie de pasajes de numerosos Padres de la Iglesia y teólogos medievales, que contribuyeron a formar una sólida tradición doctrinal sobre el tópico bajo escrutinio.

Al margen de que entre los pensadores cristianos anteriores o posteriores al siglo VI se adviertan ciertas diferencias de énfasis en sus respectivas formulaciones -los primeros insistiendo en el ingreso por el oído de María; los segundos enfatizando la Palabra emitida por el Altísimo en el momento de ser escuchada por la Virgen-, parece evidenciarse que unos y otros interpretan esa tesis en un sentido plenamente metafórico y simbólico: el oído de María no sería en este prodigioso episodio un canal genésico por el cual habría pasado materialmente el hálito/fluido fecundador de Dios Padre/Espíritu Santo ni, menos aún, el Verbo divino encarnado en forma de embrión o feto, sino el canal acústico por el que la Virgen recibió y aceptó de forma inmaterial la Palabra de Dios Padre proponiéndole la concepción/encarnación de la Palabra (Verbo) de Dios Hijo en su vientre sin desmedro de su virginidad.

De hecho, podríamos interpretar así el razonamiento de los Padres de la Iglesia y los teólogos medievales que tan metafórica y simbólicamente defienden la conceptio per aurem: la Palabra, Logos o Verbo de Dios se hace carne (Verbo encarnado) en el seno de María en el mismo instante en que -y solo después de que-, tras penetrar por el oído de María como sonido, voz o vocablo (Verbo en hálito resonante, Logos/ Pneuma) emitido por Dios, es asentido con fe irrestricta por la Virgen al concluir su diálogo (dia-Logos) con el arcángel Gabriel.

Es útil, por último, precisar que, pese a su vigencia durante casi un milenio, esta peculiar idea de la conceptio per aurem terminaría siendo prohibida a mediados del siglo XVI por el Concilio de Trento (1545-1563). Tal prohición obedeció esencialmente al posible riesgo de que esa simbólica metáfora se tomara al pie de la letra, en el sentido de que el oído de María fuese percibido como una especie de conducto genésico («genital») a través del cual se habría introducido físicamente el Hijo de Dios encarnado en forma de embrión o feto. 


\section{FUENTES Y BIBLIOGRAFÍA}

\subsection{FUENTES}

S. Álvarez Campos (ed.), Corpus Marianum Patristicum (Continens omnia alicuius momenti de Beata Maria Virgine documenta quae reperiri potuerunt in scriptoribus septem primorum saeculorum. Collegit ex novissimis editionibus et digessit Sergius Alvarez Campos), Burgos, Ediciones Aldecoa, 1970-1981, 7 vols.

Biblia Sacra iuxta Vulgatam Clementinam. Nova editio (logicis partitionibus aliisque subsidiis ornata a Alberto Colunga et Laurentio Turrado), Madrid, La Editorial Católica, Col. Biblioteca de Autores Cristianos, 2005 $5^{12}, 1.255$ p. + mapas s.p.

Documenta Catholica Omnia. Magisterium Paparum. Leo I, Magnus.

Evangelio Armenio de la Infancia. En Santos Otero 2006, 353-354.

Faustus Reiensis, Sermo 2. En Álvarez Campos 1981, vol. VI, 106.

Himnógrafo anónimo, Hymnus 11. En Álvarez Campos 1981, vol. V, 170.

Isaac de Antioquia, Sermo 3. En Álvarez Campos 1981, vol. V, 183.

Isaac de Antioquia, Carmen 6. En Álvarez Campos 1981, vol. V, p. 184.

Jacob de Sarug (Iacobus Sarugensis), Homilia de Mariae visitatione. En Álvarez Campos 1981, vol. V, 48.

Jacob de Sarug, Epistula ad monachos Conventus Mar Bassus, 15. En Álvarez Campos 1981, vol. V, 92.

J-P. Migne (ed.), Patrologiae Cursus Completus, Series Latina, Paris, Garnier, 1844-1864, 221 vols. (Colección de patrística latina citada con la abreviatura PL).

J-P. Migne (ed.), Patrologiae Cursus Completus, Series Graeca, Paris, Garnier, 1857-1867, 166 vols. (Colección de patrística griega citada con la abreviatura PG).

Obras completas de San Agustín, Madrid, La Editorial Católica, Col. Biblioteca de Autores Cristianos, 1977-1995, 41 vols.

Pseudo-Augustinus, sive Sermones Caillau-Saint-Yves, In Natali Domini, 2. En Álvarez Campos 1981, vol. VI, 269.

San Agobardo de Lyon (Agobardus Lugdunensis), Liber de Correctione Antiphonarii, VIIVIII. PL 104, 331-332.

San Agustín de Hipona, Augustinus, Sanctus, Opera. PL 32-40.

San Agustín de Hipona, Obras completas de San Agustín, Madrid, La Editorial Católica, Col. Biblioteca de Autores Cristianos, 1977-1995, 41 vols.

San Agustín de Hipona, Sermo XXII, De versu 3 Psalmi LXVII. PL 38, 148-155.

San Agustín de Hipona, Sermo de tempore barbarico. PL 40, 699-708.

San Bernardo de Claraval, Obras completas de San Bernardo. Edición bilingüe. Promovida por la Conferencia Regional Española de Abades Cistercienses. Vol. II. Tratados (2 $\left.{ }^{\circ}\right), \mathrm{La}$ Editorial Católica, Col. Biblioteca de Autores Cristianos, Madrid, 1984.

San Bernardo de Claraval, In laudibus Virginis Matris. Homilia IV, 11. En Obras completas de San Bernardo, op. cit., 1984, 676. 
San Efrén de Siria, Hymni de Nativitate 7. En Alvarez Campos 1970, vol. II, 484.

San Efrén de Siria, Hymni de Ecclesia 35. En Alvarez Campos 1970, vol. II, 509.

San Efrén de Siria, Hymni de virginitate 23. En Alvarez Campos 1970, vol. II, 509.

San Efrén de Siria, Explanatio Evangelii concordantis 20, 32. En Alvarez Campos 1970, vol. II, 535.

San Pedro Damián, Sermo XI. De Annuntiatione Beatissimae Virginis Mariae (XXV Mart.). PL 144, 558.

San Proclo de Constantinopla, Oratio I. De laudibus S. Mariae. PG 65, 679-691.

San Proclo de Constantinopla, Homilia de Mariae visitatione. En Álvarez Campos 1981, vol. V, 48.

San Proclo de Constantinopla, Oratio III. De Incarnatione Domini nostri Iesu Christi. PG 65, 707.

San Zenón de Verona, Tractatuum Sancti Zenonis episcopi veronensis Liber Primus. Tractatus XIII. De circumcisione, X, 19-20. PL 11, 352.

San Zenón de Verona, Tractatuum Sancti Zenonis Episcopi Veronensis Liber Secundus. Tractatus VIII. De Nativitate Domini II. PL 11, 413.

A. de Santos Otero, Los Evangelios Apócrifos (Colección de textos griegos y latinos, versión crítica, estudios introductorios y comentarios por Aurelio de Santos Otero), Salamanca, La Editorial Católica, Col. Biblioteca de Autores Cristianos, 148, 2006, 705 p.

Vita Virginis. Fragmentum II B. En Álvarez Campos 1981, vol. V, 236-237.

\subsection{BIBLIOGRAFÍA}

F. Antal, Florentine painting \& its social background. The bourgeois Republic before Cosimo de' Medici's advent to power: XIV and early XV centuries, New York, Icon editions / Harper \& Row, s.a. (1948), 388 p.

J. A. de Aldama, María en la Patrística de los siglos I y II, Madrid, Biblioteca de Autores Cristianos, 1970, $380 \mathrm{p}$.

G. A. Anderson, The Genesis of Perfection: Adam and Eve in Jewish and Christian Imagination, Kentucky, Westminster John Knox Press, 1955, 257 p.

B. Baert, «The Annunciation Revisited. Essay on the Concept of Wind and the Senses in Late Medieval and Early Modern Visual Culture», Critica d'Arte (sin otros datos), p. 57-68. https://lirias.kuleuven.be/bitstream/123456789/378446/1/bozza+articolo+Baert. pdf [Acceso : 30/03/2014]

L. Bréhier, L'art chrétien. Son développement iconographique des origines à nos jours. París, Librairie Renouard-H. Laurens éditeur, 1928, p. 268.

E. Borsook, The mural painters of Tuscany. From Cimabue to Andrea del Sarto, Oxford, Clarendon Press, 1980, lvii,157 p. + il., s.p.

L. Bréhier, L'art chrétien. Son développement iconographique des origines à nos jours, París, Librairie Renouard-H. Laurens éditeur, 1928, 480 p.

F. Cabrol, Fernand y H. Leclercq, Dictionnaire d'Archéologie Chrétienne et de Liturgie, Paris, Letouzey et Ané, 1924-54, 12 vols. Abreviado como DACL. 
F. Cabrol, «Annonciation (Fête de 1')», DACL, 1924, Tome 1, 2e Partie, col. 2241-2255.

E. Carli, Duccio di Buoninsegna, Milano, Aldo Martello, 1961, 33 p. + 63 p. lám.

E. Carli, Duccio, Milano, Electa, 1999, 163 p.

E. Castelnuovo, La pittura in Italia. Il Duecento e il Trecento, Torino, Electa, 1985, 2 vols.

B. Cole, Giotto and Florentine painting 1280-1375, New York, Icon Editions / Harper \& Row, 1976, 209 p.

B. Cole, Sienese painting. From its origins to the fifteenth century, New York, Icon Editions, Harper \& Row, 1980, 243 p.

N. Constas, Proclus of Constantinopole and the Cult of the Virgin in Late Antiquity: homilies 1-5, texts and translations, Leiden, Brill, 2003, $450 \mathrm{p}$.

Dictionnaire de Théologie Catholique. Contenant l'exposé des doctrines de la théologie catholique, leurs preuves et leur histoire. (Commencé sous la direction de A. Vacant, E. Mangenot. Continué sous celle de E. Amann), Paris, Letouzey et Ane, 1999-1950, 15 vols. dobles (30 tomos). Abreviado como DTC.

Enciclopedia Cattolica, Città del Vaticano, Ente per l'Enciclopedia Cattolica e per il Libro Cattolico, 1948-1954, 12 vols. Abreviado como Enc. Catt.

R. Fremantle, Florentine Gothic Painters. From Giotto to Masaccio. A guide to painting in and near Florence 1300 to 1450, London, Martin Secker and Warburg, 1975, 665 p. +40 pl.

E. Garrison, Early Italian painting. Selected studies, vol. I: Panels and frescoes; vol. II, Manuscripts, London, Pindar Press, 1984, 2 vols.

J.I. González Montañés, «Parvulus Puer in Annuntiatione Virginis. Un estudio sobre la iconografía de la Encarnación», Espacio, Tiempo y Forma, Serie VIl, Historia del Arte, 9 (1996), 11-45.

A. Grabar, Les voies de la création en iconographie chrétienne. Antiquité et Moyen Âge, Paris, Flammarion, Coll. Idées et recherches, 1979, 341 p.

P. Hills, The light of early Italian painting, New Haven and London, Yale University Press, $1987,160 \mathrm{p}$.

Y. Hirn, The Sacred Shrine: A Study of the Poetry and Art of the Catholic Church, 1909 (reimpr. Boston, Beacon Press, 1957).

D. Iogna-Prat, É. Palazzo y D. Russo (eds.), Marie. Le culte de la Vierge dans la société médiévale (Préface de G. Duby), Paris, Bauchesne, 1996, 623 p.

E. Jones, «The Madonna's conception through the ear. A contribution to the relation between aesthetics and religion» (1914), reimpr. en E. Jones, Essays in Applied Psycho-Analysis. Essays in Applied Psycho-Analysis, London/Vienna: The International Psycho-Analytical Press, 1923, Cap. VIII, 261-359.

M. R. Katz (ed.), Divine mirrors. The Virgin Mary in the visual arts (With essays by Melissa R. Katz and Robert A. Orsi), Oxford / New York, Oxford University Press, 2001, xxi, 297 p.

W. Kindler, «Representation of the 'conceptio per aurem' in the Christian culture area of the middle ages», Zeitschrift für Laryngologie, Rhinologie, Otologie und ihre Grenzgebiete, 49 (10) (1970), 696-702. 
H. Leclercq, «L'Annonciation dans l'art», Dictionnaire d'Archéologie Chrétienne et de Liturgie, Tome 1, 2e Partie, Paris, Librairie Letouzey et Ané, 1924, col. 2255-2267.

C. Limentani y M. Pietrogiovanna, Retables. L'âge gothique et la Renaissance, Paris, Citadelles \& Mazenod, 2001, 419 p.

H.B.J. Maginnis, The world of the early Sienese painter (With a translation of the Sienese Breve dell'Arte dei Pittori, by Gabriele Erasmi), Pennsylvania, Pennsylvania State University Press, 2001, xxi, 310 p.+ ill., s.p.

H.B.J. Maginnis, Painting in the age of Giotto. A historical revaluation, Pennsylvania, Pennsylvania State University Press, 1997, 217 p. + ill., s.p.

É. Mâle, L'art religieux du XIIIe siècle en France. Étude sur les origines de l'iconographie du Moyen Âge et sur ses sources d'inspiration, Paris, Armand Colin, Coll. Livre de poche. Serie Art, 1898 (reimpr. 1968), 2 vols.

É. Mâle, L'Art religieux du XIIe siècle en France. Étude sur les origines de l'iconographie du Moyen Âge, Paris, A. Colin, (1924) 19667, iv,463 p.

É. Mâle, L'art religieux du XIIIe siècle en France. Étude sur les origines de l'iconographie du Moyen Âge et sur ses sources d'inspiration, Paris, Armand Colin, 1988 8768 p.

É. Mâle, L'art religieux de la fin du Moyen Âge en France. Étude sur l'iconographie du Moyen Âge et sur ses sources d'inspiration, Paris, A. Colin, 19957, xi,570 p.

G. McMurray Gibson, The Theater of Devotion: East Anglian Drama and Society in the Late Middle Ages, Chicago, University of Chicago Press, 1994, 252 p.

M. Meiss, Painting in Florence and Siena after the Black Death. The arts, religion and society in the mid-fourteenth century, New York: Harper \& Row, 1965, xii,195 p.

D. Norman, Siena and the Virgin. Art and politics in a late medieval city state, New Haven / London, Yale University Press, 1999, viii,251 p.

R. Oertel, Early Italian Painting to 1400, London, Thames and Hudson, 1966, 376 p.

R. Offner, Studies in Florentine painting. The fourteenth century, New York, Junius Press, 1927 (reimpr. 1972), v,149 p. + il., s.p.

M. Pierini, L'art à Sienne, Paris, Hazan, 2001, 192 p.

J. Poeschke, Fresques italiennes du temps de Giotto, 1280-1400, Paris, Citadelles \& Mazenod, 2003, 455 p.

J. Poucet, L'Évangile selon Jean d'Outremeuse (XIVe s.) Autour de la Naissance du Christ (Myreur, I, p. 307-347 passim). Commentaire, inserto en la revista digital Folia Electronica Classica, 28 (2014), s.p.

L. Réau, Iconographie de l'art chrétien. Tome 2, Iconographie de la Bible. Part II, Nouveau Testament, Paris, Presses Universitaires de France, 1957, 769 p.

F. Remigereau, «Les enfants faits par l'oreille. Origine et fortune de l'expression», dans Mélanges 1945. 5. Études linguistiques, Paris, 1947, p. 115-176 (Publications de la Faculté des Lettres de l’Université de Strasbourg, 108).

J.M. Salvador González, «La doctrina de Jacob de Sarug sobre la conceptio per aurem como posible fuente literaria en la iconografía medieval de La Anunciación», Mirabilia Ars, 1 (2014), 96-130. 
G. Schiller, Ikonographie der christlichen Kunst. Band 4,1, Die Kirche, Gütersloh, Gütersloher VerlagHaus, 1988, 341 p.

G. Schiller, Ikonographie der christlichen Kunst. Band 4,2, Maria, Gütersloh, Gütersloher VerlagHaus, 1980, 472 p.

V.M. Schmidt (ed.), Italian panel painting of the Duecento and Trecento, New Haven and London, National Gallery of Art, Washington, distributed by Yale University Press, 2002, $527 \mathrm{p}$.

A. Smart, The Dawn of Italian Painting 1250-1400, Oxford, Phaidon, 1978, 152 p.

G.E. Solberg, «Altarpiece types and regional adaptations in the work of Taddeo di Bartolo». In Schmidt (ed.) 2002, 199-227.

L. Steinberg, «'How shall this be?’ Reflections on Filippo Lippi’s «Annunciation» in London, Part I», Artibus et Historiae. An art anthology, 16 (1987), 25-44.

J.H. Stubblebine, Duccio di Buoninsegna and his school. Vol. I. Text, Princeton, Princeton University Press, c. 1979, 226 p.

J.H. Stubblebine, Duccio di Buoninsegna and his school. Vol. II. Plates, Princeton, Princeton University Press, c. 1979, xvi,329 p.

M.-L. Thérel, Le triomphe de la Vierge-Église. Sources historiques, littéraires et iconographiques, Paris, Éditions du CNRS, 1984, 374 p.

G.M. Toscano, Il pensiero cristiano nell'arte, Bergamo, Istituto Italiano d'Arti Grafiche, 1960, 3 vols.

M. Trens, María. Iconografía de la Virgen en el arte español, Madrid, Plus Ultra, 1947, 715 p.

K. Urbaniak-Walczak, Die «conceptio per aurem»: Untersuchungen zum Marienbild in Ägypten unter besonderer Berücksichtigung der Malereien in El-Bagawat, Altenberge, Oros Verlag, Col. Arbeiten zum spätantiken und koptischen Ägypten, 2.), 1991.

A. Vacant, A., E. Mangenot y É. Amann, Dictionnaire de théologie catholique. Contenant l'exposé des doctrines de la théologie catholique, leurs preuves et leur histoire. (Commencé sous la direction de A. Vacant, E. Mangenot. Continué sous celle de E. Amann), Paris: Letouzey et Ané, 1909-1950, 15 vols. dobles (30 tomos).

$\mathrm{Ph}$. Verdier, Le couronnement de la Vierge. Les origines et les premiers développements d'un thème iconographique, Paris, Librairie J. Vrin, 1980, 277 p.

T. Verdon, Maria nell'arte europea (Didascalie a cura di Filippo Rosi), Milano: Electa, 2004, $227 \mathrm{p}$.

M. Vloberg, La Vierge et l'Enfant dans l'art français, Paris, Arthaud, 1954 (1933), 323 p.

VV.AA., «Annunciazione», Enciclopedia Cattolica, op. cit., vol. I, 1948, col. 1382-210.

VV.AA. «Maria Santissima - Madre di Gesù Cristo, Figlio di Dio fattosi uomo», Enciclopedia Cattolica, op. cit., vol. VIII, 1952, col. 76-118.

C.H. Weigelt, Sienese painting of the Trecento, New York, Hacker Art Books, 1974, 108 p.+ 120 lám. 